\title{
Large Differences in Livelihood Responses and Outcomes to Increased Conservation Enforcement in a Protected Area
}

\author{
Joel Persson ${ }^{1}$ D . Scott Ford ${ }^{1}$ - Anousith Keophoxay ${ }^{2}$ - Ole Mertz ${ }^{1}$. Jonas Østergaard Nielsen ${ }^{3}$. \\ Thoumthone Vongvisouk ${ }^{4} \cdot$ Michael Zörner $^{5}$
}

Accepted: 10 September 2021 / Published online: 7 October 2021

(c) The Author(s), under exclusive licence to Springer Science+Business Media, LLC, part of Springer Nature 2021, corrected publication 2021

\begin{abstract}
Despite the popularity of integrated conservation and development approaches to protected area management, adjacent communities increasingly face livelihood dilemmas. Yet understanding of how market processes and conservation enforcement interact to influence livelihood responses remains limited. Targeting eight villages in Nam Et-Phou Louey (NEPL) National Park in northern Lao PDR, we draw on survey data with 255 households, 93 semi-structured interviews, and meso-level data on village conditions to examine how residents navigate associated livelihood dilemmas. A cluster analysis reveals five livelihood types with divergent capacities to engage in market development and cope with enforcement pressures. We show how market linkages, historical conservation interventions, and local access conditions shape livelihoods and differences between villages. Our approach yields a nuanced picture of how global conservation efforts result in an uneven distribution of costs and benefits at local scales. Conservation measures must account for highly divergent capacities to cope with access loss and diversify livelihoods.
\end{abstract}

Keywords Protected Areas · Livelihoods $\cdot$ Mixed Methods $\cdot$ Integrated Conservation and development $\cdot$ Lao PDR

\section{Introduction}

Protected Areas (PAs) are essential tools in the global agenda for nature conservation (Lewis et al., 2019). Today covering $15.4 \%$ of all terrestrial land (UNEP-WCMC et al., 2021), an expansion of the global PA estate may be imminent with several experts calling for even higher levels of coverage in light of ongoing and rapid loss of species worldwide (Büscher $e t$ al., 2017; Di Marco et al., 2019; Ellis \& Mehrabi, 2019).

Joel Persson

jgp@ign.ku.dk

1 Department of Geosciences and Natural Resource Management, University of Copenhagen, Copenhagen, Denmark

2 Independent Researcher, Vientiane, Laos

3 Department of Geography and IRI THESys, Humboldt-Universität zu Berlin, Quartier Stadtmitte Friedrichstraße 191, 10117 Berlin, Germany

4 Faculty of Forest Sciences, National University of Laos, Dongdok, Xaythany District, Vientiane, Laos

5 Catholic University of Eichstätt-Ingolstadt, Ostenstraße 26, 85072 Eichstätt, Germany
However, decades of research on the social and environmental consequences of PAs paint a heterogeneous picture of their effectiveness at protecting nature and their impacts on local communities (Blom et al., 2010; Oldekop et al., 2016). PA conservation creates costs and benefits that are often unequally distributed across spatial scales, local contexts, and households, requiring trade-offs at multiple levels (Beauchamp et al., 2018; Blom et al., 2010; McShane et al., 2011; Suich, 2010). Particularly in the Global South, PAs tend to imply substantial costs for local residents (Dawson et al., 2017; Oldekop et al., 2010; Roe et al., 2015). Such costs are often associated with physical displacement including evictions, a loss of access to natural resources for customary and income-generating purposes, human rights abuses in the course of rule enforcement, and elite capture of benefits (Chechina et al., 2018; Chomba et al., 2015; McElwee, 2010; Oldekop et al., 2016; Sheely, 2015). Interventions thus tend to exacerbate the social-ecological dilemmas facing local residents as livelihood improvement and biodiversity goals come into conflict (Southworth et al., 2006).

Law enforcement has historically had a strong foundation in conservation and is a primary means for enhancing PAs (Ferraro \& Hanauer, 2015; Gray et al., 2018; Johnson 
et al., 2016). However, law enforcement alone is inadequate to ensure PA integrity and tends to be lax, especially in places where livelihoods rely on access to PA resources (McElwee, 2010; Phromma et al., 2019). Moreover, while PA enforcement may have theoretical backing as a measure to change resource-use behaviours, a cohort of issues complicates its implementation in practice, including inadequate incentives for enforcement officers and competing interests between PA staff and local residents (Robinson et al., 2010). In a PA in Bangladesh, for instance, Mukul et al. (2014) suggest that law enforcement was largely ineffective in halting illegal forest degradation practices, arguing that economic incentives for local residents are more effective.

The limitations and social consequences of strict law enforcement have made market-based instruments to create alternative income-generating activities for local residents increasingly popular (Holmes \& Cavanagh, 2016). Ecotourism, certified commodity production, carbon credits, or other alternative livelihood interventions create new opportunities (Holmes \& Cavanagh, 2016; Naidoo et al., 2019). However, alternative livelihood interventions tend to be based on simplifications of agent behaviours that can have unintended outcomes for conservation (Wright et al., 2016). These include assumptions that people will substitute current income sources with the new activities rather than complementing them; that local communities are homogenous entities; and that individual activities are scalable across a population. Interventions must therefore be evaluated in light of the multidimensional nature of livelihoods, including tenure rights and prevailing market institutions, to account for the uneven distribution of social impacts of PAs (McElwee, 2010; Roe et al., 2015; Wright et al., 2016).

An equitable management of PAs can improve both the legitimacy and effectiveness of conservation (Schreckenberg et al., 2016; Woodhouse et al., 2018). In a meta-analysis, Oldekop et al. (2016) find that positive socio-economic outcomes and fewer livelihood restrictions were associated with improved conservation outcomes. Moreover, local communities tend to oppose conservation policies and undermine PA rules when they perceive their livelihoods to be compromised (Kidegesho \& Mtoni, 2008; Soliku \& Schraml, 2018). Understanding how local residents navigate conservation-livelihood dilemmas is consequently a core policy and academic concern (Igoe, 2006; Schleicher et al., 2019; Wunder et al., 2014), particularly in contexts where market expansion for land-based commodities is shaping livelihoods at the frontiers of PAs (Roth \& Dressler, 2012).

While livelihoods are grounded in the institutions and conditions of a particular place, they are increasingly shaped by distant economic and political processes, as demonstrated in research on telecoupling (Andriamihaja et al., 2019; Baird \& Fox, 2015; Eakin et al., 2014; Friis
\& Nielsen, 2019). Macro-level processes are mediated at the meso-level to then shape the conditions in which local livelihoods are embedded (Medina et al., 2009; Newton et al., 2016; Taylor, 2016). For rural residents in PAs, macro-level processes relate to the development of market institutions and government interventions. For instance, market linkages established at the village level can drive natural resource commodification and will result in diverse livelihood outcomes depending on context-specific factors tied to location, infrastructure, and market institutions (De Haan \& Zoomers, 2005; Friis \& Nielsen, 2017; Mahanty \& Milne, 2016; Suich, 2010).

Similarly, the livelihood consequences of PA interventions are mediated by location-specific factors (Jansen et al., 2006; Soltani et al., 2012; Thapa Karki, 2013). Research highlights that PAs are often unevenly enacted across a given territory, affecting local livelihoods differently depending on conditions of the household and local context (Thapa Karki, 2013). For instance, Baird and Leslie (2013) show that being closer to a PA in Tanzania was associated with greater livelihood diversification. Clements et al. (2014) find that households closer to a PA in Cambodia were significantly better off, which could partly be explained by village-level characteristics such as distance to the city. In addition, access to conservation livelihoods such as ecotourism is determined largely by village context. Hoang et al. (2020) show that ability to derive benefits differed by village membership, while $\mathrm{Ma}$ et al. (2018) demonstrate how tourism benefits are associated with community assets and are spatially differentiated. Local attitudes towards PAs also tend to be a factor of village location and experiences with PA interventions (Badola et al., 2012). For instance, Guerbois et al. (2013) show that residents closer to a PA in Zimbabwe, and experiencing more restrictions, view the PA more negatively. Perception of benefits from PAs is also shaped by location-specific factors (Amoah \& Wiafe, 2012; Nyaupane \& Poudel, 2011; Vodouhê et al., 2010). However, studies either conduct in-depth analyses of only a few villages or are based on large-n multivariate analyses that do not adequately engage with differences between villages and the diverse types and levels of PA intervention found in a PA. For the latter, village-level characteristics are normally integrated as variables in multivariate models such as distance, market presence, or infrastructure (Guerbois et al., 2013; Hoang et al., 2020), without a critical engagement with how meso-level conditions shape local livelihood responses at the frontiers of PAs.

In this article, we present an alternative approach to nuancing livelihood impacts at PA frontiers that combines multivariate quantitative analyses and in-depth analysis of village contexts to understand how residents of local communities navigate dilemmas in the context of accel- 
erating market-based livelihood development. In doing so we engage with the meso-scale to explain differences in livelihood outcomes resulting from PA engagements. We hypothesize that capacities to respond to PA pressures and opportunities are shaped by household capitals and contextspecific conditions, in particular market linkages and the spatial features of people's livelihood activities. We use Nam Et-Phou Louey (NEPL) National Park in northern Lao PDR (Laos) as a case study.

\section{Methods}

\section{Study Area: Nam Et-Phou Louey National Park and Villages}

The forest landscapes of northern Laos typify livelihood dilemmas at the intersection of market development and nature conservation. Regional economic growth and consequent demand for land-based commodities have caused market linkages to increase drastically in recent years through cross-border trade with Vietnam and China, rising urban demand, and a government policy to commercialise smallholder agriculture (Vongvisouk et al., 2014, 2016). This is accelerating transitions from shifting cultivation to agricultural intensification and commodification (Hepp et al., 2019; Kallio et al., 2019; Ornetsmüller et al., 2018). At the same time, forest conservation maintains a central importance in policymaking, including through strengthening the existing PA network (World Bank, 2020a, 2020b). Laos currently has 24 PAs covering approximately $18 \%$ of the country, three of which have recently been upgraded to national parks (MoNRE, 2016; World Bank, 2020a, 2020b). Despite having important impacts on local residents, including historical measures of eviction and overlaps with customary land, and although the inequitable distribution of livelihood consequences from commercialisation and conservation is of major importance (Castella et al., 2013; Lagerqvist et al., 2014; Newby et al., 2014), only a few studies have explored the livelihood implications of Laos' agricultural transformation for people living in the vicinity of PAs (Ingalls \& Dwyer, 2016; Martin et al., 2018), most doing so indirectly when investigating land-use change (Castella et al., 2013; Cole et al., 2019).

Nam Et-Phou Louey (NEPL) National Park combines restrictive exclusionary measures with Integrated Conservation and Development (ICD) projects (Persson et al., forthcoming). Officially delineated in 1993, NEPL remained a 'paper park' until it started receiving continuous management support in 2000 and law enforcement began in 2005
Fig. 1 Map of NEPL National Park (Source: author's own based on data from WCS)

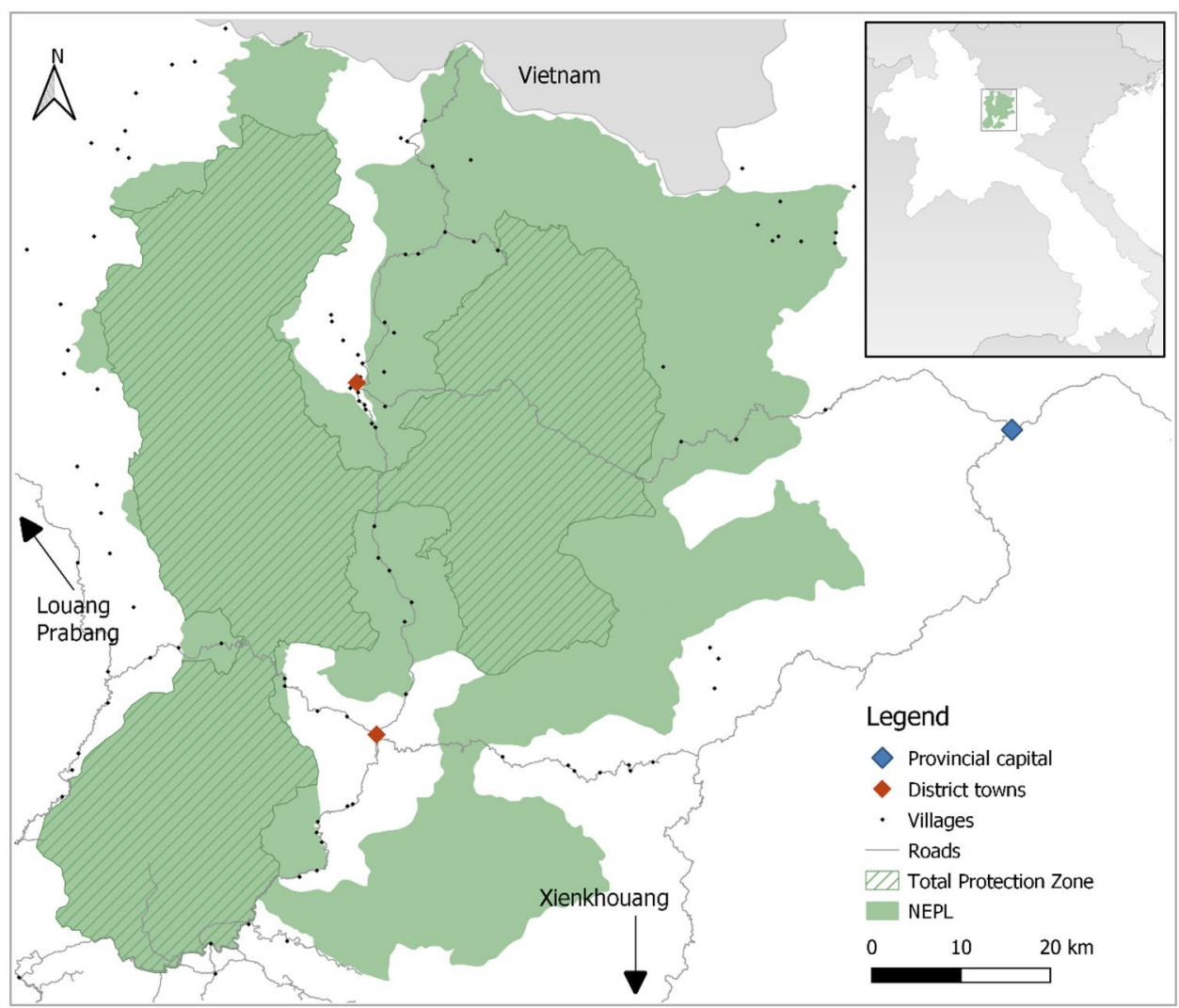


(Corbett, 2008; Johnson et al., 2012). Based on data from Wildlife Conservation Society (WCS), NEPL covers nearly 500,000 hectares of mountainous forestland, zoned into 198,000 hectares of Controlled Use Zone (CUZ), where limited subsistence activities are permitted, and 300,000 hectares Totally Protected Zone (TPZ), where access is strictly forbidden (Fig. 1). A critical biodiversity area in Southeast Asia, NEPL harbours several globally important and threatened animal species (Johnson et al., 2009). The PA was originally framed around safeguarding a small tiger population that seems to have been extirpated (Rasphone et al., 2019). Nevertheless, NEPL is a flagship for environmental policymaking in Laos. The PA is important for the country's Green Growth programme as a scalable PA management model and, in 2019, was upgraded to the country's first national park (World Bank, 2020a, 2020b).

The NEPL Management Unit (NEPLMU) is a government entity in charge of daily operations and receives technical and financial support from WCS. While NEPLMU staff members lead park-specific activities, district and provincial agencies are responsible for coordinating and implementing various projects and government programmes on forest governance and agricultural development (Broegaard et al., 2017). The result is a bundle of measures to govern natural resource use, ranging from alternative livelihood support, ecotourism and social campaigns to land-use zoning, sanctioning and law enforcement. An estimated 91,500 people live in 283 villages within and adjacent to NEPL, with a smaller population of 23,000 living in the CUZ (Martin et al., 2018). Local residents practice shifting cultivation for upland rice combined with foraging for Non-Timber Forest Products (NTFPs), cash crop agriculture, livestock herding and wildlife hunting. Increasingly, these practices are commercially oriented and opportunities for off-farm and nonfarm income are growing.

[Fig. 1].

\section{Data Collection \& Analysis}

Table 1 outlines the data collection procedures. Preliminary interviews were conducted in October-November 2018, while the mixed-method data collection at village sites was conducted in July-August 2019. We followed a concurrent triangulation design in which extensive and intensive methods were employed to generate separate datasets that were analysed in parallel, mainly for cross-validation and corroboration (Creswell, 2009). In order to capture the multidimensional ways that PA interventions interact with local land-use and livelihood practices in the context of rapid market expansion, it was necessary to establish the dominant livelihood trajectories and how these are shaped by market linkages at the village level. For this, we combined cluster and statistical analyses based on household survey data with meso-level variables from key-informant interviews and secondary data. Eight villages were selected (renamed to pseudonyms based on the Lao word for village: Ban) to demonstrate a spread of socioeconomic and political contexts at the border of the TPZ and permit inter-village comparisons (Table 2). Since we were interested in the causal relationships between conservation interventions and livelihood adaptations, moreover, semi-structured interviews with households, coupled with a land-use mapping and discussion activity, provided qualitative data to interrogate household adaptations. Together, these methods provided a robust understanding of the major factors influencing capacities to respond to PA pressures and opportunities. Qualitative data was analysed using QSR NVivo 12, while statistical analyses were performed using IBM SPSS Statistics 27.

The household survey instrument was developed based on a literature review and in consultation with three national researchers. Revisions were made after two rounds of testing with 2-3 participants. Most survey respondents were conversant in Lao. For those that were not, one of the enumerators who spoke the ethnic language (Hmong) or a family member facilitated interpretation. Survey interviews lasted 45-70 min and were administered mostly at respondents' homes. The aim was to operationalise a number of variables to analyse the relationship between dominant livelihood practices, experiences with park interventions, and park attitudes.

\section{Cluster Analysis}

Cluster analysis was employed to differentiate between different livelihood groups and identify dominant strategies. We largely followed the approach described in Köbrich $e t$ al. (2003) and Estevez-Moreno et al. (2019), performing agglomerative hierarchical clustering using Ward's method of minimum variance as the clustering method (see Appendix 1 for details). We performed the analysis on the normalised values of the variables of interest as well as on the factors from a factor analysis, and conducted a two-step nonhierarchical clustering to verify the initial groupings (see Appendix 2) (Parker et al., 2015). Proportions of income from different sources were used as proxies for livelihood activities, and we triangulated the cluster results with qualitative survey responses on major income changes experienced at household level and secondary statistical data for the village level (Soltani et al., 2012).

The variables used for the cluster analysis are described in Table 3, based on income from the past year. All income measures were converted from Lao Kip (LAK) to US Dollars (USD) based on the 2019 exchange rate ( 1 USD $=8,696$ LAK). We divided livestock into "small" and "large" to account for their different husbandry practices. Final clusters were profiled by cross-tabulating livelihood variables 


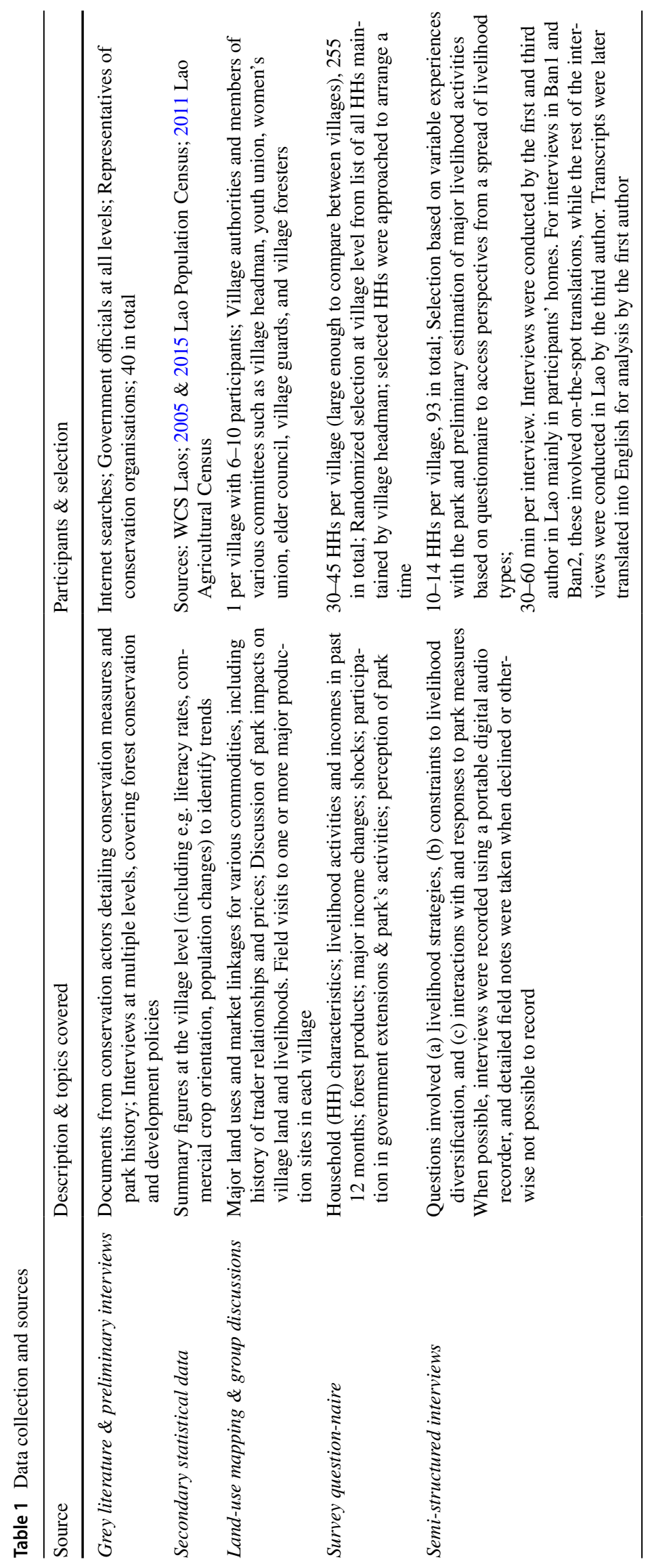


Table 2 Village characteristics

\begin{tabular}{|c|c|c|c|c|c|c|c|c|}
\hline & Ban1 & Ban2 & Ban3 & Ban4 & Ban5 & Ban6 & Ban7 & Ban8 \\
\hline Total no. HHs 2018* & 244 & 41 & 49 & 63 & 68 & 79 & 65 & 68 \\
\hline $\begin{array}{l}\text { No. HHs surveyed (inter- } \\
\text { viewed) }\end{array}$ & $45(14)$ & $30(13)$ & $30(10)$ & $30(11)$ & $30(11)$ & $30(11)$ & $30(12)$ & $30(11)$ \\
\hline Major income sources & $\begin{array}{l}\text { Livestock Gov't } \\
\text { NTFPs }\end{array}$ & $\begin{array}{l}\text { Livestock } \\
\text { NTFPs }\end{array}$ & $\begin{array}{l}\text { Livestock } \\
\text { Fruit }\end{array}$ & Weaving Poultry & NTFPs & NTFPs & $\begin{array}{l}\text { Livestock } \\
\text { Maize }\end{array}$ & $\begin{array}{l}\text { Livestock } \\
\text { NTFPs }\end{array}$ \\
\hline $\begin{array}{l}\text { Mean (median) income in } \\
\text { USD** }\end{array}$ & $2,105(983)$ & $2,946(2,715)$ & $1,862(856)$ & $3,192(2,275)$ & $1,331(1,092)$ & $\begin{array}{l}1,621 \\
(798)\end{array}$ & $1,157(397)$ & $1,102(756)$ \\
\hline$\%$ HHs selling crops $* *$ & 24.4 & 13.3 & 50.0 & 60.0 & 36.7 & 43.3 & 60.0 & 40.0 \\
\hline$\%$ HHs with paddy land** & 2.2 & 93.3 & 16.7 & 73.3 & 16.7 & 10.0 & 10.0 & 76.7 \\
\hline$\%$ HHs with a loan** & 13.3 & 66.7 & 26.7 & 53.3 & 23.3 & 46.7 & 46.7 & 46.7 \\
\hline $\begin{array}{l}\text { Distance to nearest town } \\
\text { centre }(\mathrm{km})\end{array}$ & 60.4 & 18.2 & 20.3 & 28.1 & 34.3 & 37.4 & 21.4 & 6.3 \\
\hline Distance to $T P Z(\mathrm{~km})$ & 3.5 & 3.8 & 2.7 & 1.6 & 2.9 & 0.0 & 2.5 & 2.9 \\
\hline Distance to NEPLMU $(\mathrm{km})$ & 225.2 & 18.2 & 20.3 & 28.1 & 79.8 & 82.8 & 21.4 & 43.0 \\
\hline Presence of park $* * *$ & Low & Medium & Medium & High & Low & Low & High & Medium \\
\hline
\end{tabular}

*Based on WCS data

**Based on survey results

***Based on assessment of level of intervention

and cluster membership. We performed Kruskal-Wallis tests for significance and Mann-Whitney U post-hoc tests for continuous variables, adjusting the p-values based on Bonferroni-Holms, and chi-squared tests for dichotomous categorical variables. Lastly, we conducted a multinomial logistic regression analysis to assess which asset endowments explain differences between cluster groups, having removed variables with high multi-collinearity and those that did not exhibit significant relationships. We use the Sustainable Livelihood Framework to guide the analysis, breaking our indicators down into physical, natural, social, financial, and human capital (Amevenku et al., 2019; Huy Phan et al., 2019; Tittonell et al., 2010).

[Table 3].

\section{Park Indices}

We constructed one index to capture attitudes towards NEPL and a second on engagement in NEPL activities (see Appendix 3). Ten Likert Scale statements reflecting dif- ferent dimensions including perceived impacts on income generation and food sufficiency (Ven, 2016) were chosen to construct the park attitude index by summing the scores. Inter-item correlation was below 0.397 (with a mean of 0.200), and a Cronbach's Alpha of 0.711 suggests robustness. The index was rescaled from 0 to 100 to improve interpretation. The park engagement index captures the multidimensional ways in which park conservation interact with people's daily lives. Therefore, we combined ten variables that reflect awareness, information access, and participation in activities. Higher weights were given to variables that, based on discussions with NEPL staff and key informants, reflect higher engagement. Inter-item correlation was below 0.478 for any pair of variables and showed a Cronbach's Alpha of 0.724, and the index was also rescaled from 0 to 100 to improve interpretation. We conducted a multivariate linear regression of the park engagement index to assess the extent to which livelihood grouping and village membership influence engagement (see Appendix 5). A wealth index was
Table 3 Variables used for clustering

\begin{tabular}{ll}
\hline Variable & Description \\
\hline Proportion farm income & Sale of all crops \\
Proportion NTFP income & Sale of NTFPs from a pre-defined list of 10 \\
Proportion public sector income & Government position, pension transfers, NEPL work, teacher \\
Proportion remittances & Income from remittances (cash transfers from outside the village) \\
Proportion private sector income & Construction work, owning a shop, farm labourer, trader \\
Proportion large livestock income & Sale of buffaloes and cattle \\
Proportion small livestock income & Sale of poultry, pigs, farmed fish, and goats \\
\hline
\end{tabular}


constructed based on a list of items to compare household wealth status (see Appendix 3).

\section{Qualitative Analysis and Land-use Mapping}

We analysed transcripts and notes from 93 household interviews to identify common themes in household responses to NEPL conservation measures and their spatial dimensions. An initial codebook, informed by theory and the research questions, was developed. The first author conducted the coding. This focused on household livelihood adaptation to park interventions, and reasons for (not) participating in park activities. Broad codes were subsequently refined into specific themes related to different livelihood practices (farming, NTFP collection, livestock grazing, participation in conservation activities) (Corbin \& Strauss, 2008). We then compared coded responses with the household livelihood portfolio and village-level conditions. We sought to go beyond the presentation of codes by grounding the analysis in literature and background knowledge of PA conservation, shifting between different levels of abstraction to relate themes to theory, integrating notions of scale, and comparing across groups (Bazeley, 2009). The quotes selected were thus illustrative of broader patterns and logics (Cope, 2005). The land-use mapping activity provided important meso-level data to ground the qualitative assessments. Lasting between $1.5-2.5 \mathrm{~h}$ and involving 6-10 participants, this served as a catalyst for discussing the area-based impacts of park interventions and government land-use regulations, particularly along the village borders, and how resulting constraints affected the spatial dimensions of residents' livelihood activities.

\section{Results}

We differentiate livelihood clusters according to multiple livelihood dimensions, highlighting a striking inter-group inequality, continued reliance on land and natural resources for livelihoods, high, though unequal, levels of marketization of production, and limited remuneration from park activities. Combining these results with the qualitative data analysis, four dimensions of how park activities influence livelihood diversification options are analysed: access to land for farming, livestock grazing, NTFP collection, access to alternative livelihood options, and participation in park activities.

\section{Dominant Livelihood Types}

The cluster analysis reveals five major livelihood groups. Figure 2 and Table 4 characterise each cluster based on income and asset comparisons. The largest group, "NTFP Collectors", consists of subsistence farmers with low income levels and nearly $80 \%$ of cash income from NTFPs, mainly red mushroom (Russula rosea Pers., often called Russula lepida in Laos), but also other products such as bamboo shoots, broom grass, wild root crops and fruits. "Commercial Farmers" are households with income from crop sales and/ or small livestock. The "Workers \& Migrants" group is composed of households with off-farm, nonfarm and private sector incomes and/ or receiving remittances, translating into a higher per capita income than Commercial Farmers. Nonfarm work includes work in the district town or the provincial capital, such as in construction or as a driver. "Herders" have high wealth, own the largest numbers of cattle and buffaloes and make high incomes from sale of large livestock. Having the highest proportion of paddy rice production and access to loans translate into a higher rice production than all other groups. Moreover, they have the highest NTFP income and very low farming income. The "Government Workers" group consists of households with very high income, mainly from public sector sources, who own 16 of 30 cars and trucks. They also hold large loans, are much more likely to have a household member on a village committee and to report having more than four people they can rely on in times of need.

NTFP Collectors score significantly lower than other groups on a number of indicators. Members do not commercialise their farm production and are the least diversified group in terms of income sources. Nearly all households that do not have a single income source greater than 58 USD yearly belong to this cluster $(n=27 / 30)$. NTFP Collectors are only slightly less likely to be indebted than other groups and own few physical assets and household products. They rarely cultivate paddy rice, i.e. wet rice cultivation, or participate in government extensions. Household members are also significantly less likely than other groups to be on a village committee. Commercial Farmers have a higher per capita income than NTFP Collectors and slightly higher wealth, according to the measures in our wealth index. This group also has more separate income sources and a higher proportion of paddy rice production than NTFP Collectors. The household heads of Workers \& Migrants and Government Workers have a significantly higher education than those of NTFP Collectors, and Herders and Government Workers have more adults in the household.

There are some commonalities across clusters. All groups place a priority on household rice sufficiency as even wealthy households with nonfarm income produce rice for household consumption. Only $2 \%$ of households in the sample did not produce any rice and only $9 \%$ sold rice in the past year. Members of all clusters make an income from and consume NTFPs. In addition, there are no significant differences in the way households across clusters deal with shocks such as loss of income. Likewise, there are no significant differences between income changes across groups, 


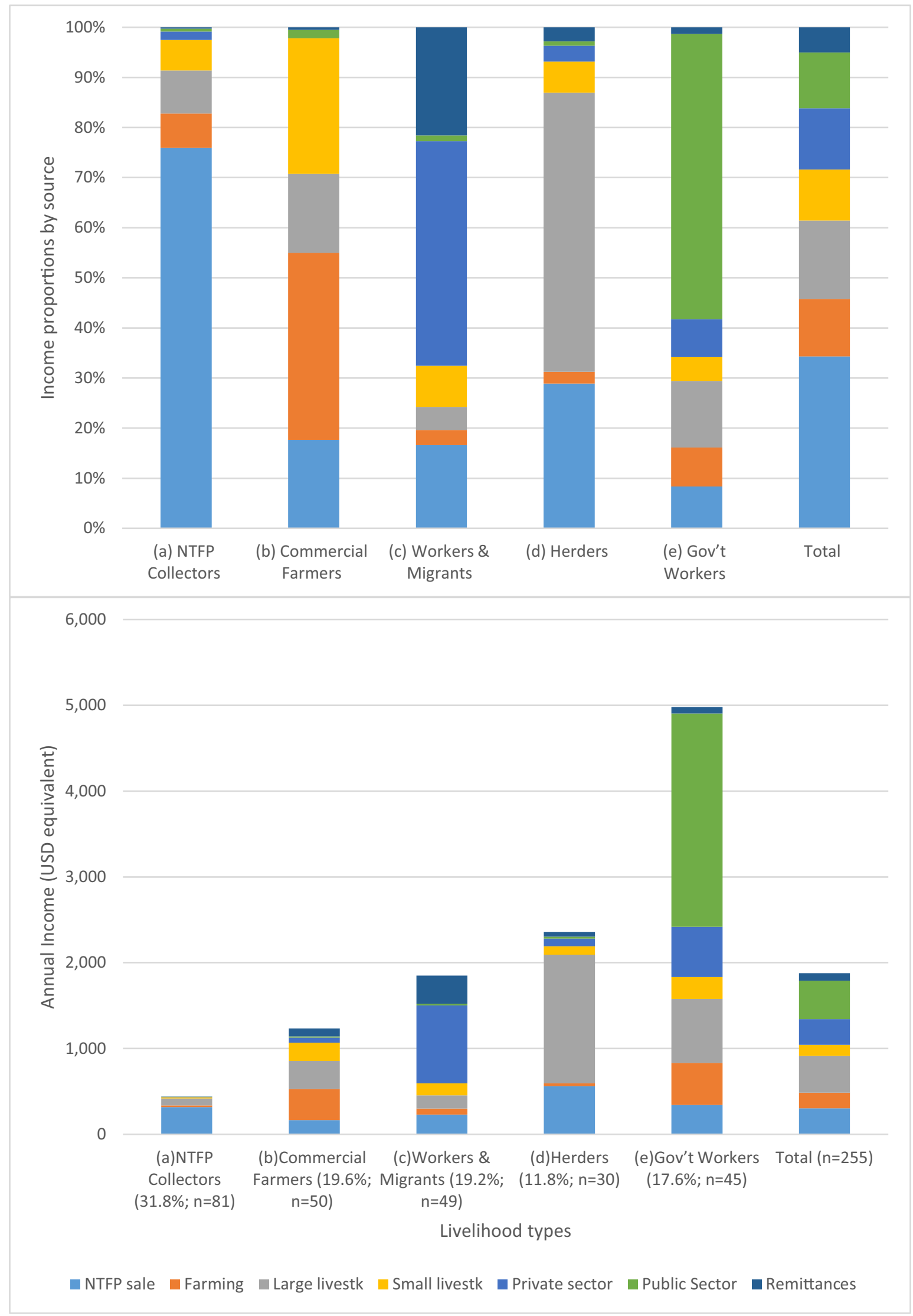

Fig. 2 Average income proportions (\%) and annual incomes (USD) by cluster 
Table 4 Comparison of proxy variables for asset endowments between cluster groups

\begin{tabular}{|c|c|c|c|c|c|c|}
\hline Variable & (a) NTFP Collectors & $\begin{array}{l}\text { (b) Commercial } \\
\text { Farmers }\end{array}$ & $\begin{array}{l}\text { (c) Workers \& } \\
\text { Migrants }\end{array}$ & (d) Herders & (e) Gov't Workers & Total \\
\hline \multicolumn{7}{|l|}{ Physical Capital } \\
\hline Wealth index & $22.36^{\mathrm{b}, \mathrm{d}, \mathrm{e}}(1.08)$ & $26.94^{\mathrm{a}, \mathrm{d}, \mathrm{e}}(1.29)$ & $27.78^{\mathrm{d}, \mathrm{e}}(2.38)$ & $35.56^{\mathrm{a}, \mathrm{b}, \mathrm{c}}(2.55)$ & $40.25^{\mathrm{a}, \mathrm{b}, \mathrm{c}}(3.07)$ & $\begin{array}{l}29.01 \\
(.96)\end{array}$ \\
\hline $\begin{array}{l}\text { Does not own } \\
\text { motorbike** }\end{array}$ & $++(\mathrm{n}=12)$ & $0(n=2)$ & $+(n=6)$ & $0(n=2)$ & $-(n=0)$ & N/A \\
\hline Owns car or truck** & $-(n=1)$ & $-(n=2)$ & $0(n=7)$ & $0(n=4)$ & $++(\mathrm{n}=14)$ & N/A \\
\hline $\begin{array}{l}\text { Owns hand trac- } \\
\text { tor*** }\end{array}$ & $-(n=9)$ & $+(n=15)$ & $-(n=9)$ & $++(n=19)$ & $0(\mathrm{n}=12)$ & N/A \\
\hline Owns fridge $* * *$ & $-(n=10)$ & $-(n=8)$ & $0(\mathrm{n}=10)$ & $0(n=10)$ & $+++(n=27)$ & N/A \\
\hline \multicolumn{7}{|l|}{ Natural Capital } \\
\hline$\%$ rice from paddy & $\begin{array}{l}5.5^{\mathrm{b}, \mathrm{c}, \mathrm{d}, \mathrm{e}} \\
(2.1)\end{array}$ & $\begin{array}{l}31.0^{\mathrm{a}, \mathrm{c}} \\
(5.3)\end{array}$ & $\begin{array}{l}20.82^{\mathrm{a}, \mathrm{b}, \mathrm{d}} \\
(5.0)\end{array}$ & $\begin{array}{l}58.3^{\mathrm{a}, \mathrm{b}, \mathrm{c}} \\
(6.5)\end{array}$ & $\begin{array}{l}34.6^{\mathrm{a}} \\
(6.7)\end{array}$ & $\begin{array}{l}24.7 \\
(2.3)\end{array}$ \\
\hline $\begin{array}{l}\text { Access to paddy } \\
\text { land }^{* * *}\end{array}$ & $-(n=8)$ & ++ & 0 & ++ & 0 & N/A \\
\hline $\begin{array}{l}\text { Rice production/ } \\
\text { capita }(\mathrm{kg})\end{array}$ & $288.8^{\mathrm{d}}(16.6)$ & $326.2^{\mathrm{e}}(24.2)$ & $256.2^{\mathrm{d}}(23.6)$ & $396.9^{\mathrm{a}, \mathrm{c}}(27.1)$ & $248.5^{\mathrm{b}}(24.5)$ & $295.5(10.3)$ \\
\hline$\%$ of rice sold & $0.37^{\mathrm{b}}$ & $6.08^{\mathrm{a}}$ & 3.02 & 4.03 & 3.18 & 2.93 \\
\hline $\begin{array}{l}\text { \# NTFP types con- } \\
\text { sumed (no diff) }\end{array}$ & $6.3(2.0)$ & $6.9(2.8)$ & $6.8(2.1)$ & $7.0(2.0)$ & $6.7(2.4)$ & $6.7(2.2)$ \\
\hline \# shocks (no diff) & $1.5(.1)$ & $1.7(.2)$ & $1.5(1.1)$ & $1.3(1.0)$ & $1.4(.1)$ & $1.5(.1)$ \\
\hline $\begin{array}{l}\text { \# crops for sale (no } \\
\text { diff) }\end{array}$ & $1.0(.1)$ & $1.1(.1)$ & $1.0(.2)$ & $0.7(.8)$ & $1.2(.2)$ & $1.0(.1)$ \\
\hline \multicolumn{7}{|l|}{ Social Capital } \\
\hline $\begin{array}{l}H H \text { on village com- } \\
\text { mittee } * * *\end{array}$ & - & 0 & 0 & + & ++ & N/A \\
\hline $\begin{array}{c}\text { Can rely on }>4 \\
\text { people }^{* *}\end{array}$ & - & 0 & - & 0 & ++ & N/A \\
\hline \multicolumn{7}{|l|}{ Financial Capital } \\
\hline $\begin{array}{l}\text { Income/ capita } \\
\text { (USD) }\end{array}$ & $65.10^{\mathrm{b}, \mathrm{c}, \mathrm{d}, \mathrm{e}}(9.19)$ & $\begin{array}{l}169.52^{\mathrm{a}, \mathrm{c}, \mathrm{d}, \mathrm{e}} \\
(20.99)\end{array}$ & $\begin{array}{l}320.12^{\mathrm{a}, \mathrm{b}, \mathrm{e}} \\
(47.65)\end{array}$ & $305.73^{\mathrm{a}, \mathrm{b}, \mathrm{e}}(42.61)$ & $745.34^{\mathrm{a}, \mathrm{b}, \mathrm{c}, \mathrm{d}}(95.41)$ & $282.93(25.01)$ \\
\hline $\begin{array}{l}\text { Herd size (\# large } \\
\text { livestock) }\end{array}$ & $2.0^{\mathrm{d}, \mathrm{e}}(.3)$ & $2.4^{\mathrm{d}, \mathrm{e}}(.4)$ & $3.7^{\mathrm{d}}(.7)$ & $17.5^{\mathrm{a}, \mathrm{b}, \mathrm{c}, \mathrm{e}}(1.9)$ & $7.4^{\mathrm{a}, \mathrm{b}, \mathrm{d}}(1.4)$ & $5.2(.4)$ \\
\hline \# income sources & $2.2^{\mathrm{b}, \mathrm{c}, \mathrm{d}, \mathrm{e}}(.2)$ & $4.1(.2)$ & $4.0(.3)$ & $4.1(.3)$ & $4.9(.4)$ & $3.6(.1)$ \\
\hline $\begin{array}{l}\text { No income } \\
\text { source }>58 \\
U_{S D^{* * *}}\end{array}$ & $++++(\mathrm{n}=27 / 30)$ & - & - & - & - & N/A \\
\hline Total loan (USD) & $\begin{array}{l}552^{\mathrm{d}} \\
(117)\end{array}$ & $\begin{array}{l}634^{\mathrm{d}} \\
(158)\end{array}$ & $\begin{array}{l}859 \\
(188)\end{array}$ & $\begin{array}{l}1878^{\mathrm{a}, \mathrm{b}} \\
(416)\end{array}$ & $\begin{array}{l}1232 \\
(259)\end{array}$ & $\begin{array}{l}903 \\
(93)\end{array}$ \\
\hline $\operatorname{Loan} * * *$ & - & - & 0 & ++ & 0 & N/A \\
\hline $\begin{array}{l}\text { Own large live- } \\
\text { stock*** }\end{array}$ & - & 0 & - & ++ & + & N/A \\
\hline \multicolumn{7}{|l|}{ Human Capital } \\
\hline HH size & $7.0^{\mathrm{d}}(.3)$ & $7.1^{\mathrm{d}}(.4)$ & $7.1^{\mathrm{d}}(.5)$ & $8.8^{\mathrm{a}, \mathrm{b}, \mathrm{c}}(.7)$ & $8.1(.5)$ & $7.4(.2)$ \\
\hline $\begin{array}{l}\text { Education of } \mathrm{HHH} \\
\text { (years) }\end{array}$ & $3.9^{\mathrm{c}, \mathrm{e}}(.4)$ & $4.4^{\mathrm{e}}(.4)$ & $5.6^{\mathrm{a}, \mathrm{e}}(.5)$ & $5.0^{\mathrm{e}}(.6)$ & $8.6^{\mathrm{a}, \mathrm{b}, \mathrm{c}, \mathrm{d}}(.6)$ & $5.3(.2)$ \\
\hline $\begin{array}{l}\text { \# adults in } \mathrm{HH} \\
\text { (>15 years) }\end{array}$ & $3.8^{\mathrm{d}, \mathrm{e}}(.2)$ & $4.1(.2)$ & $4.4(.4)$ & $5.3^{\mathrm{a}}(.4)$ & $5.1^{\mathrm{a}}(.4)$ & $4.4(.2)$ \\
\hline $\begin{array}{l}\text { Participated in live- } \\
\text { stock extension } * * *\end{array}$ & - & + & 0 & + & + & N/A \\
\hline $\begin{array}{l}\text { Age of } H H H \\
\text { (years) (no diff) }\end{array}$ & $38.6(1.3)$ & $41.8(1.8)$ & $40.2(2.0)$ & $42.8(2.1)$ & $41.0(1.5)$ & $40.5(.8)$ \\
\hline
\end{tabular}


Table 4 (continued)

\begin{tabular}{|c|c|c|c|c|c|c|}
\hline Variable & (a) NTFP Collectors & $\begin{array}{l}\text { (b) Commercial } \\
\text { Farmers }\end{array}$ & $\begin{array}{l}\text { (c) Workers \& } \\
\text { Migrants }\end{array}$ & (d) Herders & (e) Gov't Workers & Total \\
\hline \multicolumn{7}{|c|}{ NEPL Park Variables } \\
\hline $\begin{array}{l}\text { Park engagement } \\
\text { index }\end{array}$ & $\begin{array}{l}27.8^{\mathrm{b}, \mathrm{c}, \mathrm{d}, \mathrm{e}} \\
(1.9)\end{array}$ & $\begin{array}{l}38.2 \\
(3.6)\end{array}$ & $\begin{array}{l}38.4 \\
(3.2)\end{array}$ & $\begin{array}{l}40.6 \\
(3.3)\end{array}$ & $\begin{array}{l}44.4 \\
(3.5)\end{array}$ & $\begin{array}{l}36.3 \\
(1.4)\end{array}$ \\
\hline $\begin{array}{l}\text { NEPL income past } \\
\text { year (USD) }\end{array}$ & $\begin{array}{l}0.6^{\mathrm{b}, \mathrm{e}} \\
(0.4)\end{array}$ & $\begin{array}{l}16.0^{\mathrm{a}} \\
(5.3)\end{array}$ & $\begin{array}{l}5.8^{\mathrm{b}} \\
(3.6)\end{array}$ & $\begin{array}{l}1.4 \\
(0.9)\end{array}$ & $\begin{array}{l}13.3^{\mathrm{a}} \\
(7.5)\end{array}$ & $\begin{array}{l}6.9 \\
(1.8)\end{array}$ \\
\hline $\begin{array}{l}\text { NEPL income past } \\
5 \text { years (USD) }\end{array}$ & $\begin{array}{l}4.7^{\mathrm{b}, \mathrm{d}, \mathrm{e}} \\
(2.1)\end{array}$ & $\begin{array}{l}43.1 \\
(17.9)\end{array}$ & $\begin{array}{l}24.9 \\
(9.5)\end{array}$ & $\begin{array}{l}10.0 \\
(5.5)\end{array}$ & $\begin{array}{l}49.5 \\
(17.7)\end{array}$ & $\begin{array}{l}24.6 \\
(5.2)\end{array}$ \\
\hline $\begin{array}{l}\text { Participation rates } \\
\text { patrolling/moni- } \\
\text { toring }\end{array}$ & $17.3 \%$ & $18 \%$ & $22.4 \%$ & $40 \%$ & $31.1 \%$ & $23.5 \%$ \\
\hline $\begin{array}{l}\text { Park attitude } \\
\text { index (no diff) }\end{array}$ & $\begin{array}{l}49.0 \\
(2.8)\end{array}$ & $\begin{array}{l}42.4 \\
(2.9)\end{array}$ & $\begin{array}{l}45.6 \\
(2.7)\end{array}$ & $\begin{array}{l}41.8 \\
(4.0)\end{array}$ & $\begin{array}{l}48.8 \\
(3.5)\end{array}$ & $\begin{array}{l}46.2 \\
(1.3)\end{array}$ \\
\hline
\end{tabular}

Letter indicates significant difference between the two groups using $\mathrm{p}<.05$ significance level. The number in brackets shows the standard error. For dichotomous categorical variables, $(-), 0$, and $(+)$ indicates less, neither, and more likely, respectively, with $* * * \mathrm{p}<.01, * * \mathrm{p}<.05$, and $*$ $\mathrm{p}<.10$. "no diff" indicates no significant differences between groups

meaning groups with fewer income sources experienced an equal amount of significant income fluctuations.

Results from the multinomial logistic regression show which asset endowments influence the likelihood of not belonging to the NTFP Collectors cluster (see Appendix 4). It includes all variables that were shown to have significant relationships after checking for multi-collinearity. Market links for different livelihood activities at the household level account for differences, in addition to a few other variables reflecting asset endowments such as household size, owning a production or luxury good, and household head education level (Table 5).

Examining how the clusters are spread across the villages indicates a strong influence of village-level characteristics ( $\mathrm{p}<0.0005$; Cramer's V $=0.354$ ). NTFP Collectors dominate in a number of villages, including Ban3, Ban5, Ban6, and Ban7, while Commercial Farmers are prominent in Ban4 and slightly in Ban7 and Ban8 (Fig. 3). Over half of the Herders are in Ban2, only one in neighbouring Ban3, and none in Ban4. Government Workers are dominant in Ban1, and are quite evenly spread across the other villages, while
Workers \& Migrants account for less than $10 \%$ in Ban5, Ban6, and Ban7.

Table 4 indicates some structural differences between livelihood groups regarding their interactions with NEPL. A bivariate regression analysis of the park attitude index shows that there are no significant differences between livelihoods groups, meaning all groups on average have a similar attitude towards NEPL. Looking more closely at some of the statements, however, reveals that Commercial Farmers are more likely to claim that NEPL has affected their family's ability to obtain sufficient food (chi-sq $p=0.036)$ and that they would likely make more income if there was no PA (chi-sq $p=0.010$ ). A multivariate linear regression model of the park attitude index shows that, when accounting for park engagement and village membership, cluster membership does indeed add some predictive power to the model, explaining $15.5 \%$ of the variance instead of $11.4 \%$, though overall this is quite small (see Appendix 5 for details). This is not surprising since, for instance, Commercial Farmers are located in villages experiencing strong land constraints, such as Ban4.

Table 5 Main variables influencing cluster membership, ranked by importance

\begin{tabular}{|c|c|c|c|c|}
\hline & Commercial Farmer & Worker \& Migrant & Herder & Government Worker \\
\hline 1 st & Earn farm income $* * *$ & Earn nonfarm income $e^{* * *}$ & Herd size s** $^{* *}$ & Earn nonfarm income $* * *$ \\
\hline 2nd & $\begin{array}{l}\text { Earn income from small live- } \\
\text { stock*** }\end{array}$ & $\begin{array}{l}\text { Earn income from small live- } \\
\text { stock*** }\end{array}$ & Number of income sources*** & Education of $\mathrm{HHH}$ (years) ${ }^{* * *}$ \\
\hline 3 rd & $\begin{array}{l}\text { Proportion of rice production from } \\
\text { paddy* }\end{array}$ & Household size ${ }^{* *}$ & Earn farm income** & \\
\hline 4 th & & Rice production/ capita** & Earn NTFP income** & \\
\hline 5 th & & Owning a car or truck* & Owning a $\mathrm{TV}^{*}$ & \\
\hline 6th & & Herd size* & & \\
\hline
\end{tabular}

$N B$ NTFP Collectors is the reference group

$* * * \mathrm{p}<.01 * * \mathrm{p}<.05 * \mathrm{p}<.10$ 
Fig. 3 Distribution of livelihoods across village sites

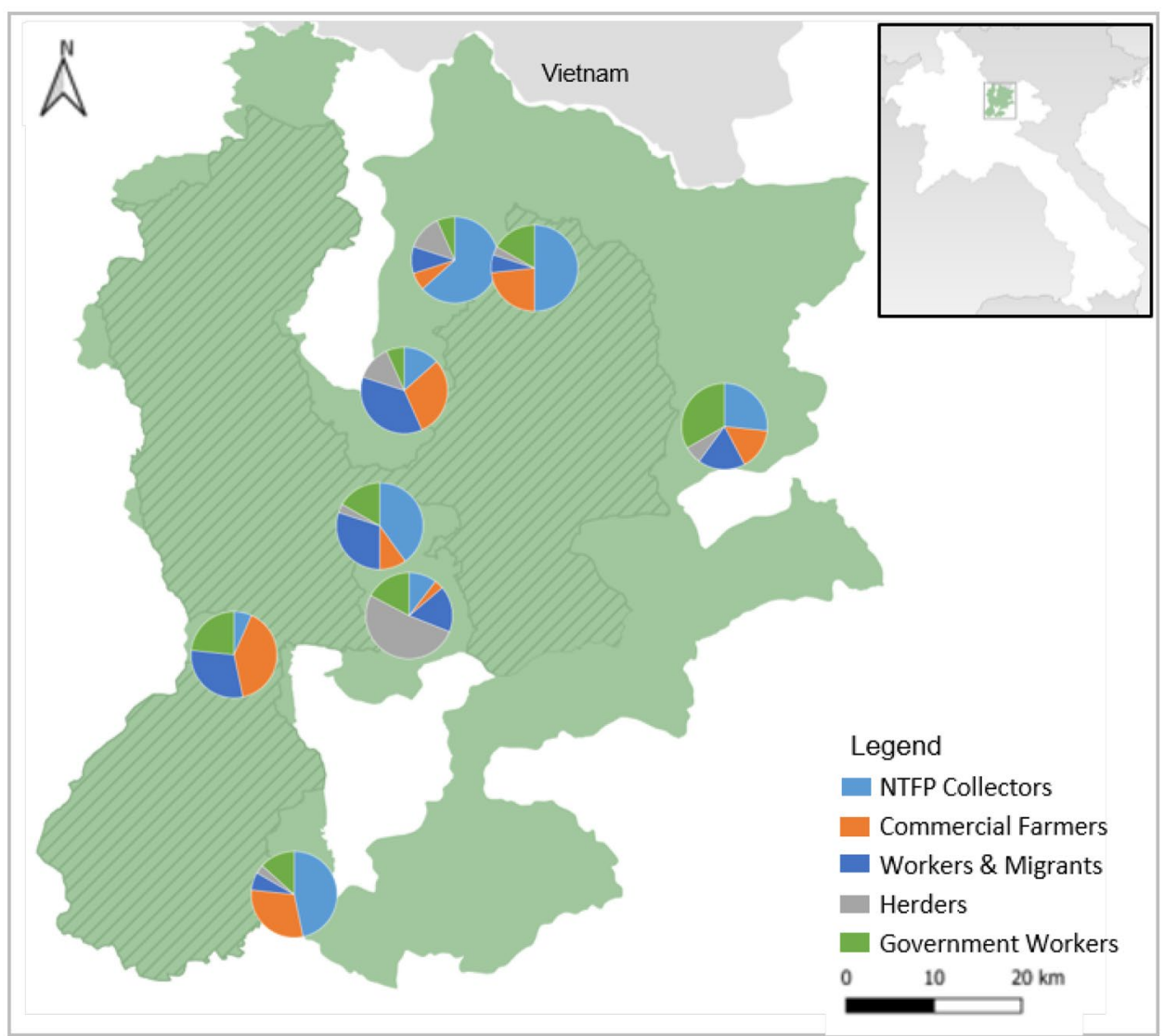

The park engagement index shows that NTFP Collectors are significantly less engaged in NEPL when we account for multiple dimensions of the park. A linear regression model shows that once we account for village membership, the effect of cluster membership on engagement is reduced, suggesting there are mediating factors at the village level. In our model, only accounting for village membership explains $27.7 \%$ of the variance while adding cluster membership explains $32.0 \%$ (model $p<0.005$, with VIF $<1.35$ ). In other words, even when accounting for village membership, NTFP Collectors appear to be excluded from NEPL activities (see Appendix 5). Moreover, NTFP Collectors have received significantly less income from remunerative park activities than both Commercial Farmers and Government Workers in the past five years, though overall the amounts are marginal compared to other income sources.

The statistical analyses have so far shown that there are village-level characteristics that influence (a) livelihood cluster membership and (b) engagement with NEPL. We now highlight the key livelihood dilemmas facing local residents in order to understand how context-specific factors mediate livelihood responses.

\section{Productive Agricultural Land}

All cluster groups rely on access to land and natural resources for their livelihood. Self-sufficiency in rice production is a priority for households but since topographical restrictions limit access to lowland agricultural fields, access to productive upland plots is the only viable means to obtain rice security for the majority of households. This makes recent rounds of land-use zoning, boundary demarcation and enforcement that have excluded many farmers from fallow plots located in the TPZ problematic. As encapsulated by one participant from Ban3,

"The government and NEPL staff have shown the boundaries of NEPL and the village agriculture area, so there is limited land... especially for upland rice. Every 2-3 years, we must move to a new area. If we do not, rice production will not be good. If farmers don't have enough rice, they will cut the forest for upland rice cultivation inside NEPL."

Residents typically equate NEPL with the TPZ, as they do not recognise their village land as being part of 
NEPL or distinguish the CUZ from the TPZ. In some villages, residents interpret recent rounds of enforcement and boundary demarcation as an expansion of the TPZ to cover previously accessible fallow land. However, the loss of fallow land depends on the village as the degree of enforcement and boundary demarcation varies extensively.

The response of local government agencies has ranged from giving official approval to access plots inside the TPZ to sanctioning. In Ban7 and Ban4, groups of farmers wrote official requests to the district government for permission to cultivate fallow plots inside the TPZ. In 2017, the district government allowed nine farming households from Ban7 to do so for one season. Farmers in Ban4, meanwhile, did not receive permission but cultivated anyway and, after paying a sanction, were permitted to harvest for one season. Other households in Ban4 were sanctioned for accessing fallows but claimed that they were unaware of the TPZ boundary. In some cases, failing yields pushed households to cultivate deep in the forest despite the risk of sanction.

Sanctions for transgressing regulations demonstrate the tensions between jurisdictional authorities and how villages experience this differently. Informants reported sanctions being paid to different offices (the village headman, district agencies, district police or the NEPLMU). In Ban2, four households cultivated fallow plots in the TPZ after gaining permission from the village authorities, and the headman dissuaded sanctioning by NEPL staff upon discovery. However, in the same village, two households were reportedly sanctioned directly by the district agency for cultivating fallow plots in the TPZ. Moreover, as indicated above, sanctions are at times perceived as an access fee. One participant, for instance, had first paid a sanction of 69 USD followed by a yearly fine of 11.50 USD to continue cultivating the plot.

The land constraints for upland plots are causing an increase in interest for paddy land, though village topography often restricts accessibility of suitable land for growing paddy rice. Unexploited potential land is usually located in areas that are difficult to access and requires extensive tilling, terracing and irrigation canals to make them productive. These are very labour-intensive and expensive investments that only the wealthiest households in three villages reported pursuing, some investing in paddy land in the district towns. Paddy investment interacts with NEPL in two ways: first, land constraints for upland plots are driving investments in paddy rice. For instance, a farmer in Ban4 stated:

"I invested in lowland rice fields because NEPL has existed in the village since 2001. NEPL doesn't allow cutting the forest, so I decided to grow paddy rice."

Second, as exemplified by experiences in Ban4, paddy farmers have often been exploiting land within the TPZ since before they first heard of NEPL. A conflict between paddy farmers and NEPL staff emerged in 2006, leading to short jail terms as farmers refused to abandon their fields. Since then, district authorities have tacitly accepted the paddy farmers' claims, which has encouraged households to invest in extending and building irrigation in the area to enhance tenure claims. More recently, however, as highlighted by a farmer who had previously been fined for cultivating land in the TPZ,

"NEPL staff came and informed us they don't permit paddy rice cultivation inside NEPL. But farmers didn't want to follow the rule because they don't have alternative land. Some had paid a lot of money to prepare the soil and wanted to keep the paddy rice field for their children."

Access to paddy land can have important path dependencies for livelihood options in a particular village, as early settlers are able to claim the most productive land. This is exemplified by the differences between Ban 2 and Ban3. When Ban2 was established, farmers claimed all suitable land for paddy rice production surrounding the village. When Ban3 was relocated adjacent to Ban2, farmers were unable to access the paddy land in their village area as it had already been claimed. The secure access to paddy land provided farmers in Ban2 with the capacity to invest in large livestock, while farmers in Ban3 have been compelled to find alternative income sources. As a result, Herders dominate Ban2, while NTFP Collectors and Workers \& Migrants are prevalent in Ban3. These dynamics illustrate how livelihood diversification opportunities are highly context-dependent. For instance, households in Ban2 reported 36 income-generating improvements in the past five years and nine decreases, compared to eight improvements and 31 decreases in Ban3. Moreover, the median income is more than three times as high in Ban2 as in Ban3 (Table 2).

\section{Communal Grazing Lands}

Conflicts over buffalo and cattle grazing inside the TPZ were present in seven of the eight villages. Farmers often retain grazing lands inside the TPZ, particularly in areas that villagers claim as old village lands, as these are usually the only suitable grassland areas to sustain large herds. Large livestock is an important form of capital investment and income source for all livelihood groups, which has been enabled by improvements in road infrastructure: $67 \%$ of households own at least one, and $70 \%(n=73 / 103)$ of loans are for livestock investment. According to traditional husbandry practices, livestock are left to forage freely in the forest. Due to the collective nature of this practice, and because many elite 
community members maintain large herds, most villages have been successful in negotiating conditional, albeit temporary, access to these grazing lands. However, land constraints are restricting this livelihood option for several villages. In Ban3, three households had sold their entire herd in the past year, citing lack of accessible grazing land, and in Ban4, four families reported selling nearly all their livestock as they were previously kept in upland plots that are now needed for rice production.

Traditional husbandry practices involve constructing small huts (sanam) in the grazing area for periodic monitoring of livestock, often in combination with other practices such as hunting wildlife for subsistence and sale. The park's policy is to forcefully remove identified sanams from the TPZ while negotiating with herders to adapt their practices and remove herds from the TPZ. As an example, herders in Ban 1 were requested to move the herd from one of their grazing areas inside the TPZ in 2012. After receiving an official letter in 2016, the sanam was destroyed by the authorities. In turn, the villagers temporarily relocated their herds to another location, but due to lack of viable land to host a large herd, they ultimately returned to the original area.

In Ban2, meanwhile, the village authorities negotiated continued use of two grazing areas overlapping with the TPZ, albeit for a restricted period, as well as maintaining sanams in these areas. The NEPLMU's suggested solution for herding households is to grow grass in upland plots, but doing so would reduce space for rice production, and likely produce inadequate amounts of grassland for many herders. The dilemmas experienced are pertinent, as noted by one participant:

"First they limit the area for upland rice, and they ask us to focus on livestock instead. But then they limit the area for livestock as well." [and], "if the NEPLMU will fine [us], we suggest they should buy our livestock. Then we will stop raising livestock in NEPL."

The proposed solution to convert one of their upland plots to fodder production has mostly been met by lack of interest due to associated constraints and the view that livestock is a form of investment and buffer capital in times of need rather than a stable income source. However, in some villages such as Ban2, wealthier households with the capital to absorb these trade-offs and the risk of poor grass production are adopting the practice. Overall, despite these dilemmas, investment in livestock remains a critical livelihood pursuit and many participants claimed that it is the most feasible option for improving livelihoods.

\section{NTFP-abundant Areas}

With $90 \%$ of sampled households reporting income from NTFPs, this is the most common income source across all livelihood groups. The practice focuses mainly on a few high-value commodities, particularly red mushroom (Russula rosea Pers.), which provides an income for $73 \%$ of households. The market links for red mushroom were first established in villages through Chinese traders in 2005-2012, and trade links have since drastically increased with some villages reporting 50 individual traders for this product, both local and external, largely as a result of improved road infrastructure.

For NTFP Collectors, sale of NTFPs, and especially red mushroom, is perceived as the only viable option to make an income. Only in Ban7 are there weak trader ties for red mushroom, although NTFP Collectors dominate this village because of a few other high-value NTFPs and because there is a scarcity of alternative income sources. Interviewees confirmed that collection points for high-value NTFPs are typically found in primary forests inside the TPZ. Though official regulations state that entry to the TPZ is not permitted for any reason, access is often negotiated and conditional. We identified a range of perspectives on access rules and experiences with NEPL enforcement between households and villages.

Because red mushroom is highly ephemeral (quick to mature), seasonal (only a few weeks per year), and has a strong price differentiation depending on age and whether it has been dried (by a factor of up to 10), a favoured strategy is to intensively collect in small groups for a few days. The mushroom is then dried in temporary huts that resemble sanams. On multiple occasions, NEPL staff had reportedly destroyed these huts and confiscated equipment from villagers in areas with stronger enforcement because they suspect that collectors also use the sanams as temporary houses to stay overnight for hunting. Collectors responded by rebuilding huts deeper in the forest and finding ways to circumvent patrols as NTFPs provide a crucial income source that is worth the risk of sanction. In villages where enforcement has been stricter, NEPL regulations have made it considerably more difficult to optimise this livelihood option. For instance, in Ban8 an NTFP trader was concerned over recent income decreases because people are no longer collecting as many NTFPs. The capacity to absorb sanctions from NEPL differs across livelihood clusters. The fines are reportedly at 23 USD for entering the TPZ, and significantly higher if the collectors bring hunting equipment.

\section{Alternative Options for Livelihood Diversification}

Across all villages, households with lower asset endowments exhibit a very strong risk averseness related to the adoption of cash crops and adopt a strategy of observation and imitation because of negative historical experiences with commercial traders and the uncertainties of market access. This was particularly acute for hybrid maize, which had been 
introduced to the region more than a decade ago. Only $15 \%$ of households reported having sold maize in the past year, and $43 \%$ stopped doing so in the past five years, citing price decrease and underpayment, unpredictable trader practices, lack of production area and issues with poor soil quality. Households have mostly reverted to rice production and in some cases diversified to other commercial crops such as ginger. Because of these experiences, households tend to wait and observe production levels, trader commitment and market accessibility before deciding to invest in new cash crops introduced by traders or through other external interventions.

However, such market links and experiences differ between villages. In Ban5, 37\% of households in the village had planted cardamom in the past year after observing favourable prices and production from one farmer, and similar approaches were reported for coffee and fruit trees in other villages. Another potential livelihood activity is the sale of small livestock, which is an important income source for all groups except NTFP Collectors. However, $20 \%$ of households reported having stopped the sale of small livestock due to diseases, sometimes having lost their entire stocks.

Nonfarm and off-farm private sector income is a limited and often ad hoc opportunity that includes work for private companies (10.2\% of households), sale of farm labour $(9.0 \%)$, sale of handicraft (7.8\%), trading (7.5\%), and owning a shop (2.8\%). Workers \& Migrants dominate this livelihood strategy, which is mostly found in Ban8, Ban3 and Ban4. Ban8 is nearby the district centre where work opportunities can be found, and in Ban4 a large governmentsupported project to promote weaving and an ecotourism project have led to income generation. In the other villages, there are fewer prospects for private sector income.

Although the NEPLMU and district authorities encourage alternative livelihoods, farmers often claimed they do not get adequate long-term extension support. Once a particular intervention for adopting new livelihood activities fails, farmers tend to revert to shifting cultivation and NTFP collection.

\section{Conservation Activities at Village Levels}

As indicated in the previous sections, the livelihood constraints and opportunities presented by NEPL conservation vary extensively between villages. Ban2 and Ban 4 have received relatively high levels of attention since the early years of management. However, in the other villages, most respondents had not heard of NEPL until a few years ago, and many lacked a basic awareness of the park. Individual participation in activities is largely determined by village membership. An ecotourism package in Ban4 has enabled nearly all households to participate in remunerative activities $(n=23)$. In addition, Ban 2 and Ban 3 are the sites of alternative livelihood activities for organic shade-grown coffee cultivation supported by the NEPLMU and WCS, but participants are normally restricted to households with spare capital and labour, and compliance to the park regulations is a precondition for eligibility. Out of nine households that reported receiving support, there was only one NTFP Collector and one Commercial Farmer. Moreover, several interviewees viewed the project as general government support and did not mention the connection between their participation and NEPL conservation. Apart from occasional meetings where regulations are disseminated, participation in NEPL activities is restricted to patrolling and monitoring. Between 5-10 households from each village reported having participated in the past five years. However, these are usually one-off events and not attractive activities, normally allocated by the headman or performed as an obligation from salaried positions as security personnel. Excluding ecotourism in Ban4, the proportion of respondents who have participated in park activities ranged from 3.3\% (Ban7) to 30\% (Ban2). Consequently, people's experiences with NEPL are dominated by more restrictive measures.

The strengthening of exclusionary conservation measures through conservation enforcement and the differential market linkages for commodities and income-generating opportunities are exacerbating livelihood dilemmas. 70.5\% of participants agreed that park regulations had become stricter in recent years and interviewees were wary of future regulations and enforcement. As we have seen, households, particularly those belonging to the NTFP Collectors group, are largely excluded from market-based livelihood commercialisation, and are often viewed as unable to engage in market processes, as indicated by statements from residents of Ban3:

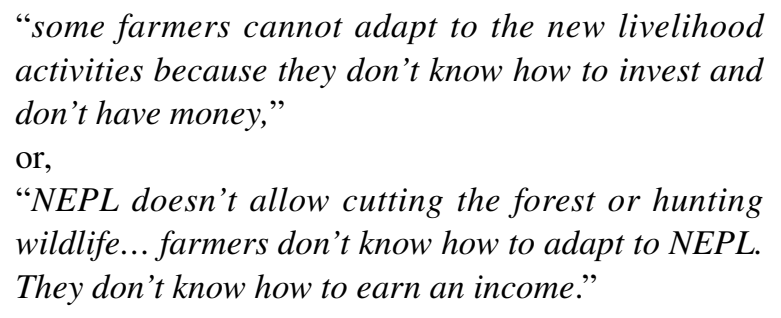

"some farmers cannot adapt to the new livelihood activities because they don't know how to invest and don't have money,"

or,

"NEPL doesn't allow cutting the forest or hunting wildlife... farmers don't know how to adapt to NEPL. They don't know how to earn an income."

Interviewees, moreover, often expressed a strong reluctance to discuss livelihood dilemmas with NEPL staff, citing concern for reprisal for simply broaching the subject. However, despite these issues, many participants also expressed an optimism that the NEPL staff and local government would be willing to renegotiate access rules and boundaries if they could demonstrate acquiescence to park regulations. 


\section{Discussion}

Livelihood diversification is ubiquitous in rural landscapes of the Global South as a way to cope with drastic as well as gradual socioeconomic and political change (Biddulph \& Amberntsson, 2017; Dorward et al., 2009; Newton et al., 2016). At the frontiers of PAs, conservation interventions can be understood in terms of how they shape diversification opportunities and should be evaluated in terms of the multidimensional nature of rural livelihoods (Wright et al., 2016). As such, measures tend to be either exclusionary by restricting access to land and environmental resources for subsistence and income-generating purposes, or inclusionary by employing market instruments to create viable alternative livelihoods or engaging local residents in (remunerative) conservation activities. Ultimately, however, PA interventions impose complex livelihood dilemmas that can be difficult to disentangle because of their relational nature and how they interact with prevailing market institutions. People's experiences with conservation are not evenly distributed across a geographical space or within the same community. While market opportunities may offset the negative impacts of conservation enforcement, for instance, market linkages differ drastically between local contexts, and people's ability to engage in market processes depends on household capital endowments. The study captures these complex interactions between PAs and livelihoods.

Our findings that livelihoods in PAs are shaped by contextspecific dimensions of resource access and the specific features of conservation interventions echo Thapa Karki (2013) and Baird and Leslie (2013). Thapa Karki (2013) employed mixed methods to show the uneven livelihood impacts across three villages and households in a PA, while Baird and Leslie (2013) position PAs as "disturbances" that affect social relationships and diversification opportunities unevenly. This is in line with research showing how people-park conflicts in the Global South often revolve around exclusionary mechanisms and that conservation measures that exacerbate livelihood dilemmas related to accessing land and natural resources can lead to conflict escalation (Boillat et al., 2018; Rechciński et al., 2019; Soliku \& Schraml, 2018).

Our analysis expands on these studies by demonstrating how livelihood dilemmas are mediated by household capital endowments and context-specific conditions including prevailing market linkages and the spatial features of livelihood activities. We highlight an important scale dimension to explain how conservation and market institutions interact to produce uneven outcomes in livelihoods. Meso-scale factors tied to the village context mediate responses to both exclusionary and inclusionary conservation measures. For instance, we found indications that location-specific land constraints arising from PA conservation engendered more negative attitudes, particularly in villages with acute land scarcity due to recent years of enforcement, while enforcement activities have created significant barriers to utilising NTFP collection in the TPZ as a livelihood strategy for residents of some villages. Micro-scale conditions, including household asset endowments, mediate individual impacts and experiences. Interlinking the two scales are the spatial dimensions of people's livelihood activities, for which we outlined four in our case, including land for agriculture, NTFP collection, livestock grazing and access to nonfarm income.

This calls attention to how macro-scale processes are mediated to shape livelihood dilemmas at the frontiers of PAs. On the market side, this includes how price signals and production conditions are established by external traders and local middle-men (Friis \& Nielsen, 2017) and the multilevel processes through which commodity markets materialise (Hauer \& Nielsen, 2020). On the conservation side, PA interventions are manifestations of interactions in multiple arenas that lead to a particular design based on the discursive practices of distant actors and donor preferences (Boillat $e t$ al., 2018; Persson \& Mertz, 2019). The livelihoods of PA residents are increasingly embedded in local and regional political economies, where the challenges of sustainable land-use cannot be rectified by ICD-type interventions as these often remain marginal to the livelihood aspirations of local residents. Approaches to capture how the distributional impacts of macro-scale processes must accommodate the interactions across scales that condition access and diversification opportunities while remaining grounded in the conditions of a particular place (Scoones, 2009).

To enhance the legitimacy of PA conservation in such contexts, it is critical that interventions explicitly account for atrisk groups in PA conservation based on a multidimensional livelihood assessment. Our findings indicate that the group with least capacity to adapt to exclusionary conservation measures and participate in inclusionary activities is also the group least capable of engaging in market processes to diversify their livelihoods (NTPF Collectors, in our case). Similar to Pasgaard and Chea's (2013) notion of "double inequity", this group is arguably subject to dual forms of inequity. The inability to adapt to changing market institutions, coupled with enhanced PA enforcement, are self-reinforcing and likely to produce negative outcomes for conservation and local livelihoods. Restrictive approaches compel households into illegal practices to cope with constraints and uncertainties, undermining prospects for sustainable environmental governance (Larrosa et al., 2016; Thapa Karki, 2013). We found indications of this in NEPL, where households with limited diversification options clear plots deep in forests, continue to collect valuable NTFPs in the TPZ despite the 
risk of sanction, or revert to shifting cultivation for rice after cash crops failed or livestock died from disease. Diversification opportunities for these households are likely to be inadequate to compensate for the loss of access to natural resources and could accelerate outmigration or other ex-post coping mechanisms. As a result, households are more likely to respond in forms of tacit dissent as residents circumvent enforcement practices they perceive to be illegitimate or cannot influence (Norgrove \& Hulme, 2006). Negotiated partial access could improve the legitimacy of PA interventions, as argued by for instance Chechina et al. (2018), but these must account for differential capacities to engage in and benefit from conservation.

Our study has implications for environmental governance in Lao PAs. Cash crop promotion and land-use intensification are key dimensions of the government's forest policies and approach to PAs (GoL, 2005; Kallio et al., 2019; World Bank, 2020a, 2020b), and part of a wider programme to reduce traditional subsistence activities based on foraging and shifting cultivation as a viable livelihood strategy. However, our results echo Junquera and Grêt-Regamey (2019) in demonstrating that unfavourable market experiences and uncertainties around future government restrictions engender a highly risk-averse approach to livelihood diversification based on observing and imitating. In our case, most households have abandoned maize as a cash crop (Cole et al., 2019; Vongvisouk et al., 2016), but rather than adopting new cash crops as found in other contexts (Mahanty \& Milne, 2016), farmers revert to upland rice production or invest in large livestock. Even when opportunities for nonfarm income generation and agricultural intensification exist, rice cultivation for household consumption and sale of NTFPs remain priorities (Hepp et al., 2019; Kallio et $a l ., 2019)$. Until market institutions and government support are strong enough to enable sustainable transitions to agricultural intensification, households are unlikely to abandon traditional livelihood practices that have proved robust to social-ecological uncertainties for generations.

Moreover, the country's Green Growth strategy positions ecotourism as a primary means to generate alternative livelihood opportunities as well as revenues to finance PA management (World Bank, 2020a, 2020b). The upgrade of NEPL to a national park was an outcome of national-level negotiations under the strategy, which implies stricter regulations and more funding to expand existing activities including enforcement practices (Persson et al., forthcoming). Despite decades of continuous support in NEPL, conservation benefits were minimal in relation to the multidimensionality of livelihood composition and in influencing people's daily lives, albeit with geographical variation. In light of the collapse of tourism since the COVID-19 outbreak (World Bank, 2021), it is questionable whether such conservation activities can provide a legitimate livelihood basis for PAs. Greater engagement with market processes that people are currently engaging in are more likely to provide viable, low-cost diversification opportunities than restricted ICD projects that are conditioned on capital endowments and compliance to regulations.

\section{Conclusion}

This article demonstrated how PA conservation and expansion of market institutions in Nam Et-Phou Louey National Park, Laos are exacerbating livelihood dilemmas for a proportion of local residents, particularly a dominant group that lacks capacities to adapt to a dynamic socioeconomic and political environment. The livelihood impacts of exclusionary and inclusionary conservation measures at PA frontiers are shaped by household capital endowments and contextspecific conditions, especially market linkages and the spatial features of livelihood activities. Our findings illustrate the importance of accounting for surrounding market processes and the multidimensionality of local livelihoods in nature conservation efforts.

The methodological approach employed, combining data collection at multiple levels and using both intensive and extensive methods, provides an alternative for evaluating livelihood impacts of conservation interventions. To understand the interactions between markets and PAs, and given the unique conditions of individual villages, both in-depth insights on local contexts and insights on indicative patterns across contexts are needed. By permitting a basis for generating statistical analyses while grounding causal propositions in intensive methods, our approach generated insight on how conservation and markets structure people's behaviours, while being attuned to individual agencies to adapt to changes.

Global efforts to enhance biodiversity are gaining greater political attention and consequently, resources are being mobilised under a number of international mechanisms, not least the Convention on Biological Diversity. These translate into local interventions that engender context-specific trade-offs and unfold unevenly across a given geographic area. The spatial dimensions of livelihood dilemmas may erupt into conflict as exclusionary conservation measures expand and livelihood interests and global conservation goals come into conflict. More research is needed to understand how people affected by conservation interventions are integrated into these processes, including what feedback and response mechanisms are available to influence related meso- and macro-scale processes.

Supplementary Information The online version contains supplementary material available at https://doi.org/10.1007/s10745-021-00267-4.

Funding This study was funded by the European Union's Horizon 2020 research and innovation programme under Marie Skłodowska-Curie Actions grant agreement No. 765408. SF was funded by the European Union's Horizon 2020 research and innovation programme under the 
Marie Skłodowska-Curie Actions grant agreement no. 766417. TV’s time was funded by the Managing telecoupled landscapes for the sustainable provision of ecosystem services and poverty alleviation project, under the Swiss Programme for Research on Global Issues for Development (R4D) Programme, funded by the Swiss National Sciences Foundation (SNSF) and the Swiss Agency for Development and Cooperation (SDC), grant number 400440152167.

\section{Declarations}

Informed Consent Written or verbal informed consent was sought for each interview and household survey, following an explanation of the research objectives, data use, anonymity and confidentiality. The research was approved by the Ethics Committee at the faculty of the first author on 18 January 2018. Related approval was obtained from institutions in which the research was carried out.

Conflicts of Interest The authors have no conflicts of interest to declare.

\section{References}

Amevenku, F. K. Y., Asravor, R. K., \& Kuwornu, J. K. M. (2019). Determinants of livelihood strategies of fishing households in the volta Basin, Ghana. Cogent Economics \& Finance, 7(1). https://doi.org/ 10.1080/23322039.2019.1595291

Amoah, M., \& Wiafe, E. D. (2012). Livelihoods of fringe communities and the impacts on the management of conservation area: The case of Kakum National Park in Ghana. International Forestry Review, 14(2), 131-144. https://doi.org/10.1505/ 146554812800923381

Andriamihaja, O. R., Metz, F., Zaehringer, J. G., Fischer, M., \& Messerli, P. (2019). Land Competition under Telecoupling: Distant Actors' Environmental versus Economic Claims on Land in North-Eastern Madagascar. Sustainability, 11(3), 851. https://doi.org/10.3390/su11030851

Badola, R., Barthwal, S., \& Hussain, S. A. (2012). Attitudes of local communities towards conservation of mangrove forests: A case study from the east coast of India. Estuarine, Coastal and Shelf Science, 96, 188-196. https://doi.org/10.1016/j.ecss. 2011.11.016

Baird, I., \& Fox, J. (2015). How Land Concessions Affect Places Elsewhere: Telecoupling, Political Ecology, and Large-Scale Plantations in Southern Laos and Northeastern Cambodia. Land, 4(2), 436-453. https://doi.org/10.3390/land4020436

Baird, T. D., \& Leslie, P. W. (2013). Conservation as disturbance: Upheaval and livelihood diversification near Tarangire National Park, northern Tanzania. Global Environmental Change, 23(5), 1131-1141. https://doi.org/10.1016/j.gloenvcha.2013.05.002

Bazeley, P. (2009). Analysing Qualitative Data: More Than 'Identifying Themes.' The Malaysian Journal of Qualitative Research, 2(2), 17.

Beauchamp, E., Clements, T., \& Milner-Gulland, E. J. (2018). Exploring trade-offs between development and conservation outcomes in Northern Cambodia. Land Use Policy, 71, 431-444. https:// doi.org/10.1016/j.landusepol.2017.11.021

Biddulph, R., \& Amberntsson, P. (2017). Whose Reality Counts? Critical Junctures in Livelihood Trajectories Under Deforestation: Whose Reality Counts? Tijdschrift Voor Economische En Sociale Geografie, 108(5), 540-553. https://doi.org/10.1111/tesg.12214

Blom, B., Sunderland, T., \& Murdiyarso, D. (2010). Getting REDD to work locally: Lessons learned from integrated conservation and development projects. Environmental Science \& Policy, 13(2), 164-172. https://doi.org/10.1016/j.envsci.2010.01.002

Boillat, S., Gerber, J.-D., Oberlack, C., Zaehringer, J., Ifejika Speranza, C., \& Rist, S. (2018). Distant Interactions, Power, and Environmental Justice in Protected Area Governance: A Telecoupling Perspective. Sustainability, 10(11), 3954. https://doi.org/10. 3390/su10113954

Broegaard, R. B., Vongvisouk, T., \& Mertz, O. (2017). Contradictory Land Use Plans and Policies in Laos: Tenure Security and the Threat of Exclusion. World Development, 89, 170-183. https:// doi.org/10.1016/j.worlddev.2016.08.008

Büscher, B., Fletcher, R., Brockington, D., Sandbrook, C., Adams, W. M., Campbell, L., Corson, C., Dressler, W., Duffy, R., Gray, N., Holmes, G., Kelly, A., Lunstrum, E., Ramutsindela, M., \& Shanker, K. (2017). Half-Earth or Whole Earth? Radical ideas for conservation, and their implications. Oryx, 51(03), 407-410. https://doi.org/10.1017/S0030605316001228

Castella, J.-C., Lestrelin, G., Hett, C., Bourgoin, J., Fitriana, Y. R., Heinimann, A., \& Pfund, J.-L. (2013). Effects of Landscape Segregation on Livelihood Vulnerability: Moving From Extensive Shifting Cultivation to Rotational Agriculture and Natural Forests in Northern Laos. Human Ecology, 41(1), 63-76. https://doi. org/10.1007/s10745-012-9538-8

Chechina, M., Neveux, Y., Parkins, J., \& Hamann, A. (2018). Balancing Conservation and Livelihoods: A Study of Forest-dependent Communities in the Philippines. Conservation and Society, 16(4), 420. https://doi.org/10.4103/cs.cs_16_182

Chomba, S., Treue, T., \& Sinclair, F. (2015). The political economy of forest entitlements: Can community based forest management reduce vulnerability at the forest margin? Forest Policy and Economics, 58, 37-46. https://doi.org/10.1016/j.forpol.2014.11.011

Clements, T., Suon, S., Wilkie, D. S., \& Milner-Gulland, E. J. (2014). Impacts of Protected Areas on Local Livelihoods in Cambodia. World Development, 64, S125-S134. https://doi.org/10.1016/j. worlddev.2014.03.008

Cole, R., Brockhaus, M., Wong, G. Y., Kallio, M. H., \& Moeliono, M. (2019). Local Agency in Development, Market, and Forest Conservation Interventions in Lao PDR's Northern Uplands. Center for Southeast Asian Studies, Kyoto University. https://doi.org/ 10.20495/seas.8.2_173

Cope, Meghan. “Chapter 14: Coding Qualitative Data.” In Qualitative Research Methods in Human Geography, edited by Iain Hay, 2nd ed. Oxford: Oxford University Press, 2005.

Corbett, J. (2008). Paper Parks and Paper Partnerships: Lessons for protected areas and biodiversity corridors in the Greater Mekong Sub-region. IUCN.

Corbin, J. M., \& Strauss, A. (2008). Basics of Qualitative Research: Techniques and Procedures for Developing Grounded Theory. SAGE Publications Inc.

Creswell, J. W. (2009). Research design: Qualitative, quantitative, and mixed methods approaches (3rd ed). Sage Publications.

Dawson, N. M., Grogan, K., Martin, A., Mertz, O., Pasgaard, M., \& Rasmussen, L. V. (2017). Environmental justice research shows the importance of social feedbacks in ecosystem service trade-offs. Ecology and Society, 22(3). https://doi.org/10.5751/ ES-09481-220312

De Haan, L., \& Zoomers, A. (2005). Exploring the frontier of livelihoods research. Development and Change, 36(1), 27-47.

Department of Statistics. (2005). Ministry of Planning and Investment. Lao PDR Population and Housing Census 2005.

Department of Planning. (2011). Ministry of Agriculture and Forestry (MAF). Lao PDR Agricultural Census 2010-2011.

Department of Statistics. (2015). Ministry of Planning and Investment. Laos Population and Housing Census 2015. 
Di Marco, M., Ferrier, S., Harwood, T. D., Hoskins, A. J., \& Watson, J. E. M. (2019). Wilderness areas halve the extinction risk of terrestrial biodiversity. Nature, 573(7775), 582-585. https:// doi.org/10.1038/s41586-019-1567-7

Dorward, A., Anderson, S., Bernal, Y. N., Vera, E. S., Rushton, J., Pattison, J., \& Paz, R. (2009). Hanging in, stepping up and stepping out: Livelihood aspirations and strategies of the poor. Development in Practice, 19(2), 240-247. https://doi.org/10.1080/09614520802689535

Eakin, H., DeFries, R., Kerr, S., Lambin, E.F., Liu, J., Marcotullio, P.J., Messerli, P., Reenberg, A., Rueda, X., Swaffield, S.R., Wicke, B., \& Zimmerer, K. (2014). Significance of Telecoupling for Exploration of Land-Use Change. In Rethinking Global Land Use in an Urban Era. MIT Press. http://www.jstor.org/stable/j.ctt9qf5p8.13

Ellis, E. C., \& Mehrabi, Z. (2019). Half Earth: Promises, pitfalls, and prospects of dedicating Half of Earth's land to conservation. Current Opinion in Environmental Sustainability, 38, 22-30. https:// doi.org/10.1016/j.cosust.2019.04.008

Estevez-Moreno, L. X., Sanchez-Vera, E., Nava-Bernal, G., EstradaFlores, J. G., Gomez-Demetrio, W., \& Sepúlveda, W. S. (2019). The role of sheep production in the livelihoods of Mexican smallholders: Evidence from a park-adjacent community. Small Ruminant Research, 178, 94-101. https://doi.org/10.1016/j. smallrumres.2019.08.001

Ferraro, P. J., \& Hanauer, M. M. (2015). Through what mechanisms do protected areas affect environmental and social outcomes? Philosophical Transactions of the Royal Society B: Biological Sciences, 370(1681), 20140267. https://doi.org/10.1098/rstb. 2014.0267

Friis, C., \& Nielsen, J. Ø. (2017). Land-use change in a telecoupled world: The relevance and applicability of the telecoupling framework in the case of banana plantation expansion in Laos. Ecology and Society, 22(4).

Friis, C., \& Nielsen, J. Ø. (2019). Telecoupling. Springer.

GoL, (2005). Ministry of Agriculture and Forestry, Government of Lao PDR. Forestry Strategy to the Year 2020 of the Lao PDR.

Gray, T. N. E., Hughes, A. C., Laurance, W. F., Long, B., Lynam, A. J., O’Kelly, H., Ripple, W. J., Seng, T., Scotson, L., \& Wilkinson, N. M. (2018). The wildlife snaring crisis: An insidious and pervasive threat to biodiversity in Southeast Asia. Biodiversity and Conservation, 27(4), 1031-1037. https://doi.org/10.1007/s10531-017-1450-5

Guerbois, C., Dufour, A.-B., Mtare, G., \& Fritz, H. (2013). Insights for Integrated Conservation from Attitudes of People toward Protected Areas Near Hwange National Park, Zimbabwe: Immigration and Integrated Conservation. Conservation Biology, 27(4), 844-855. https://doi.org/10.1111/cobi.12108

Hauer, J., \& Nielsen, J. Ø. (2020). Making land-use change and markets: The global-local entanglement of producing rice in Bagré, Burkina Faso. Geografiska Annaler: Series B, Human Geography, 1-17.https://doi.org/10.1080/04353684.2020.1723121

Hepp, C. M., Bech Bruun, T., \& de Neergaard, A. (2019). Transitioning towards commercial upland agriculture: A comparative study in Northern Lao PDR. NJAS - Wageningen Journal of Life Sciences, 88, 57-65. https://doi.org/10.1016/j.njas.2018.11.001

Hoang, T. T. H., Van Rompaey, A., Meyfroidt, P., Govers, G., Vu, K. C., Nguyen, A. T., Hens, L., \& Vanacker, V. (2020). Impact of tourism development on the local livelihoods and land cover change in the Northern Vietnamese highlands. Environment, Development and Sustainability, 22(2), 1371-1395. https://doi. org/10.1007/s10668-018-0253-5

Holmes, G., \& Cavanagh, C. J. (2016). A review of the social impacts of neoliberal conservation: Formations, inequalities, contestations. Geoforum, 75, 199-209. https://doi.org/10.1016/j.geoforum.2016. 07.014

Huy Phan, D., Quang Tran, T., Phan, A., \& Xuan Hoang, L. (2019). A quantitative analysis of farmland and households' livelihood in rural Vietnam. Human Geographies - Journal of Studies and
Research in Human Geography, 13(2). https://doi.org/10.5719/ hgeo.2019.132.1

Igoe, J. (2006). Measuring the Costs and Benefits of Conservation to Local Communities. Journal of Ecological Anthropology, 10(1), 72-77. https://doi.org/10.5038/2162-4593.10.1.7

Ingalls, M. L., \& Dwyer, M. B. (2016). Missing the forest for the trees? Navigating the trade-offs between mitigation and adaptation under REDD. Climatic Change, 136(2), 353-366. https://doi. org/10.1007/s10584-016-1612-6

Jansen, H. G. P., Pender, J., Damon, A., Wielemaker, W., \& Schipper, R. (2006). Policies for sustainable development in the hillside areas of Honduras: A quantitative livelihoods approach. Agricultural Economics, 34(2), 141-153. https://doi.org/10.1111/j. 1574-0864.2006.00114.x

Johnson, A., Goodrich, J., Hansel, T., Rasphone, A., Saypanya, S., Vongkhamheng, C., \& Venevongphet, \& Strindberg, S. . (2016). To protect or neglect? Design, monitoring, and evaluation of a law enforcement strategy to recover small populations of wild tigers and their prey. Biological Conservation, 202, 99-109. https://doi.org/10.1016/j.biocon.2016.08.018

Johnson, A., Vongkhamheng, C., \& Saithongdam, T. (2009). The diversity, status and conservation of small carnivores in a montane tropical forest in northern Laos. Oryx, 43(04), 626. https://doi. org/10.1017/S0030605309990238

Johnson, A., Vongkhamhen, C., Saypanya, S., Hansel, T., \& Strindberg, S. (2012). Using systematic monitoring to evaluate and adapt managementof a tiger reserve in northern Lao PDR. Wildlife Conservation Society.

Junquera, V., \& Grêt-Regamey, A. (2019). Crop booms at the forest frontier: Triggers, reinforcing dynamics, and the diffusion of knowledge and norms. Global Environmental Change, 57, 101929. https://doi.org/10.1016/j.gloenvcha.2019.101929

Kallio, M. H., Hogarth, N. J., Moeliono, M., Brockhaus, M., Cole, R., Waty Bong, I., \& Wong, G. Y. (2019). The colour of maize: Visions of green growth and farmers perceptions in northern Laos. Land Use Policy, 80, 185-194. https://doi.org/10.1016/j. landusepol.2018.10.006

Kideghesho, J. R., \& Mtoni, P. E. (2008). Who compensates for wildlife conservation in Serengeti? The International Journal of Biodiversity Science and Management, 4(2), 112-125.

Köbrich, C., Rehman, T., \& Khan, M. (2003). Typification of farming systems for constructing representative farm models: Two illustrations of the application of multi-variate analyses in Chile and Pakistan. Agricultural Systems, 76(1), 141-157. https://doi.org/10.1016/S0308-521X(02)00013-6

Lagerqvist, Y. F., Woollacott, L., Phasouysaingam, A., \& Souliyavong, S. (2014). Resource Development and the Perpetuation of Poverty in Rural Laos. Australian Geographer, 45(3), 407-417.

Larrosa, C., Carrasco, L. R., \& Milner-Gulland, E. J. (2016). Unintended Feedbacks: Challenges and Opportunities for Improving Conservation Effectiveness. Conservation Letters, 9(5), 316326. https://doi.org/10.1111/conl.12240

Lewis, E., MacSharry, B., Juffe-Bignoli, D., Harris, N., Burrows, G., Kingston, N., \& Burgess, N. D. (2019). Dynamics in the global protected-area estate since 2004. Conservation Biology, 33(3), 570-579. https://doi.org/10.1111/cobi.13056

Ma, J., Zhang, J., Li, L., Zeng, Z., Sun, J., Zhou, Q., \& Zhang, Y. (2018). Study on Livelihood Assets-Based Spatial Differentiation of the Income of Natural Tourism Communities. Sustainability, 10(2), 353. https://doi.org/10.3390/su10020353

Mahanty, S., \& Milne, S. (2016). Anatomy of a boom: Cassava as a 'gateway' crop in Cambodia's north eastern borderland: Anatomy of a boom. Asia Pacific Viewpoint, 57(2), 180-193. https://doi.org/10.1111/apv.12122

Martin, A., Myers, R., \& Dawson, N. M. (2018). The Park is Ruining our Livelihoods. We Support the Park! Unravelling the Para- 
dox of Attitudes to Protected Areas. Human Ecology, 46(1), 93-105. https://doi.org/10.1007/s10745-017-9941-2

McElwee, P. D. (2010). Resource Use Among Rural Agricultural Households Near Protected Areas in Vietnam: The Social Costs of Conservation and Implications for Enforcement. Environmental Management, 45(1), 113-131. https://doi.org/10.1007/ s00267-009-9394-5

McShane, T. O., Hirsch, P. D., Trung, T. C., Songorwa, A. N., Kinzig, A., Monteferri, B., Mutekanga, D., Thang, H. V., Dammert, J. L., Pulgar-Vidal, M., Welch-Devine, M., Peter Brosius, J., Coppolillo, P., \& O'Connor, S. (2011). Hard choices: Making trade-offs between biodiversity conservation and human wellbeing. Biological Conservation, 144(3), 966-972. https://doi. org/10.1016/j.biocon.2010.04.038

Medina, G., Pokorny, B., \& Weigelt, J. (2009). The power of discourse: Hard lessons for traditional forest communities in the Amazon. Forest Policy and Economics, 11(5-6), 392-397. https://doi.org/10.1016/j.forpol.2008.11.004

MoNRE. (2016). National Biodiversity Strategy and Action Plan 2016-2025. Ministry of Natural Resources and Environment. Vientiane, Laos.

Mukul, S. A., Herbohn, J., Rashid, A. Z. M. M., \& Uddin, M. B. (2014). Comparing the effectiveness of forest law enforcement and economic incentives to prevent illegal logging in Bangladesh. International Forestry Review, 16(3), 363-375. https:// doi.org/10.1505/146554814812572485

Naidoo, R., Gerkey, D., Hole, D., Pfaff, A., Ellis, A. M., Golden, C. D., Herrera, D., Johnson, K., Mulligan, M., Ricketts, T. H., \& Fisher, B. (2019). Evaluating the impacts of protected areas on human well-being across the developing world. Science Advances, 5(4), eaav3006. https://doi.org/10.1126/sciadv. aav3006

Newby, J., Cramb, R., \& Sakanphet, S. (2014). Forest Transitions and Rural Livelihoods: Multiple Pathways of Smallholder Teak Expansion in Northern Laos. Land, 3(2), 482-503. https://doi. org/10.3390/land3020482

Newton, P., Miller, D. C., Byenkya, M. A. A., \& Agrawal, A. (2016). Who are forest-dependent people? A taxonomy to aid livelihood and land use decision-making in forested regions. Land Use Policy, 57, 388-395. https://doi.org/10.1016/j.landusepol. 2016.05.032

Norgrove, L., \& Hulme, D. (2006). Confronting Conservation at Mount Elgon, Uganda: Confronting Conservation at Mount Elgon. Uganda. Development and Change, 37(5), 1093-1116. https:// doi.org/10.1111/j.1467-7660.2006.00514.x

Nyaupane, G. P., \& Poudel, S. (2011). Linkages among biodiversity, livelihood, and tourism. Annals of Tourism Research, 38(4), 1344-1366. https://doi.org/10.1016/j.annals.2011.03.006

Oldekop, J. A., Bebbington, A. J., Brockington, D., \& Preziosi, R. F. (2010). Understanding the Lessons and Limitations of Conservation and Development. Conservation Biology, 24(2), 461-469. https://doi.org/10.1111/j.1523-1739.2010.01456.x

Oldekop, J. A., Holmes, G., Harris, W. E., \& Evans, K. L. (2016). A global assessment of the social and conservation outcomes of protected areas: Social and Conservation Impacts of Protected Areas. Conservation Biology, 30(1), 133-141. https://doi.org/ 10.1111/cobi.12568

Ornetsmüller, C., Castella, J.-C., \& Verburg, P. H. (2018). A multiscale gaming approach to understand farmer\&\#8217;s decision making in the boom of maize cultivation in Laos. Ecology and Society, 23(2). https://doi.org/10.5751/ES-10104-230235.

Parker, P., Thapa, B., \& Jacob, A. (2015). Decentralizing conservation and diversifying livelihoods within Kanchenjunga Conservation Area. Nepal. Journal of Environmental Management, 164, 96-103. https://doi.org/10.1016/j.jenvman.2015.08.047
Pasgaard, M., \& Chea, L. (2013). Double Inequity? The Social Dimensions of Deforestation and Forest Protection in Local Communities in Northern Cambodia. Austrian Journal of South-East Asian Studies / Österreichische Zeitschrift Für Südostasienwissenschaften, 6(2), 330-355.

Persson, J., Mertz, O., \& Nielsen, J.Ø. (2021). What makes a national park? Distant interactions shape local environmental governance in protected areas. Forthcoming.

Persson, J., \& Mertz, O. (2019). Discursive Telecouplings. In C. Friis \& J. Ø. Nielsen (Eds.), Telecoupling (pp. 313-336). Springer International Publishing. https://doi.org/10.1007/978-3-03011105-2_17.

Phromma, I., Pagdee, A., Popradit, A., Ishida, A., \& Uttaranakorn, S. (2019). Protected area co-management and land use conflicts adjacent to Phu Kao - Phu Phan Kham National Park. Thailand. Journal of Sustainable Forestry, 38(5), 486-507. https://doi.org/ 10.1080/10549811.2019.1573689

Rasphone, A., Kéry, M., Kamler, J. F., \& Macdonald, D. W. (2019). Documenting the demise of tiger and leopard, and the status of other carnivores and prey, in Lao PDR's most prized protected area: Nam Et - Phou Louey. Global Ecology and Conservation, 20, e00766. https://doi.org/10.1016/j.gecco.2019.e00766

Rechciński, M., Tusznio, J., \& Grodzińska-Jurczak, M. (2019). Protected area conflicts: A state-of-the-art review and a proposed integrated conceptual framework for reclaiming the role of geography. Biodiversity and Conservation, 28, 2463-2498.

Robinson, E. J. Z., Kumar, A. M., \& Albers, H. J. (2010). Protecting Developing Countries' Forests: Enforcement in Theory and Practice. Journal of Natural Resources Policy Research, 2(1), 25-38. https://doi.org/10.1080/19390450903350820

Roe, D., Booker, F., Day, M., Zhou, W., Allebone-Webb, S., Hill, N. A. O., Kumpel, N., Petrokofsky, G., Redford, K., Russell, D., Shepherd, G., Wright, J., \& Sunderland, T. C. H. (2015). Are alternative livelihood projects effective at reducing local threats to specified elements of biodiversity and/or improving or maintaining the conservation status of those elements? Environmental Evidence, 4(1). https://doi.org/10.1186/s13750-015-0048-1

Roth, R. J., \& Dressler, W. (2012). Market-oriented conservation governance: The particularities of place. Geoforum, 43(3), 363-366. https://doi.org/10.1016/j.geoforum.2012.01.006

Schleicher, J., Zaehringer, J. G., Fastré, C., Vira, B., Visconti, P., \& Sandbrook, C. (2019). Protecting half of the planet could directly affect over one billion people. Nature Sustainability, 2(12), 1094-1096. https://doi.org/10.1038/s41893-019-0423-y

Schreckenberg, K., Franks, P., Martin, A., \& Lang, B. (2016). Unpacking equity for protected area conservation. Parks, 22(2), 11-26.

Scoones, I. (2009). Livelihoods perspectives and rural development. Journal of Peasant Studies, 36(1), 171-196. https://doi.org/10. 1080/03066150902820503

Sheely, R. (2015). Mobilization, Participatory Planning Institutions, and Elite Capture: Evidence from a Field Experiment in Rural Kenya. World Development, 67, 251-266. https://doi.org/10. 1016/j.worlddev.2014.10.024

Soliku, O., \& Schraml, U. (2018). Making sense of protected area conflicts and management approaches: A review of causes, contexts and conflict management strategies. Biological Conservation, 222, 136-145. https://doi.org/10.1016/j.biocon.2018.04.011

Soltani, A., Angelsen, A., Eid, T., Naieni, M. S. N., \& Shamekhi, T. (2012). Poverty, sustainability, and household livelihood strategies in Zagros. Iran. Ecological Economics, 79, 60-70. https:// doi.org/10.1016/j.ecolecon.2012.04.019

Southworth, J., Nagendra, H., \& Munroe, D. K. (2006). Introduction to the special issue: Are parks working? Exploring human-environment tradeoffs in protected area conservation. Applied Geography, 26(2), 87-95. https://doi.org/10.1016/j.apgeog.2005.11.001 
Suich, H. (2010). The livelihood impacts of the Namibian community based natural resource management programme: A meta-synthesis. Environmental Conservation, 37(1), 45-53. https://doi.org/10.1017/ S0376892910000202

Taylor, P. (2016). Frontier commoditisation in post-socialist Southeast Asia: Frontier commoditisation. Asia Pacific Viewpoint, 57(2), 145-153. https://doi.org/10.1111/apv.12125

Thapa Karki, S. (2013). Do protected areas and conservation incentives contribute to sustainable livelihoods? A case study of Bardia National Park. Nepal. Journal of Environmental Management, 128, 988-999. https://doi.org/10.1016/j.jenvman.2013.06.054

Tittonell, P., Muriuki, A., Shepherd, K. D., Mugendi, D., Kaizzi, K. C., Okeyo, J., Verchot, L., Coe, R., \& Vanlauwe, B. (2010). The diversity of rural livelihoods and their influence on soil fertility in agricultural systems of East Africa - A typology of smallholder farms. Agricultural Systems, 103(2), 83-97. https://doi.org/10.1016/j.agsy. 2009.10.001

UNEP-WCMC, IUCN, \& NGS. (2021). Protected Planet Live Report 2021. UNEP-WCMC, IUCN and NGS: Cambridge, UK; Gland, Switzerland; and Washington, D.C., USA. https://livereport. protectedplanet.net/chapter-2

Ven, S. (2016). Residents' Participation, Perceived Impacts, and Support for Community-based Ecotourism in Cambodia: A Latent Profile Analysis. Asia Pacific Journal of Tourism Research, 21(8), 836-861. https://doi.org/10.1080/10941665.2015.1075565

Vodouhê, F. G., Coulibaly, O., Adégbidi, A., \& Sinsin, B. (2010). Community perception of biodiversity conservation within protected areas in Benin. Forest Policy and Economics, 12(7), 505-512. https://doi.org/10.1016/j.forpol.2010.06.008

Vongvisouk, T., Broegaard, R. B., Mertz, O., \& Thongmanivong, S. (2016). Rush for cash crops and forest protection: Neither land sparing nor land sharing. Land Use Policy, 55, 182-192. https:// doi.org/10.1016/j.landusepol.2016.04.001
Vongvisouk, T., Mertz, O., Thongmanivong, S., Heinimann, A., \& Phanvilay, K. (2014). Shifting cultivation stability and change: Contrasting pathways of land use and livelihood change in Laos. Applied Geography, 46, 1-10. https://doi.org/10.1016/j.apgeog. 2013.10.006

Woodhouse, E., Bedelian, C., \& Dawson, N. (2018). Social impacts of protected areas: Exploring evidence of trade-offs and synergies. In K. Schreckenberg, G. Mace, \& M. Poudyal (Eds.), Ecosystem Services and Poverty Alleviation: Trade-offs and Governance (pp. 222-240). Routledge.

World Bank. (2020a). Lao biodiversity: A priority for resilient green growth. The World Bank. https://openknowledge.worldbank.org/ bitstream/handle/10986/34131/Lao-Biodiversity-A-Priority-forResilient-Green-Growth.pdf?sequence $=4 \&$ isAllowed $=\mathrm{y}$

World Bank. (2020b). Lao PDR Forest Note: Toward Sustainable Forest Landscapes for Green Growth, Jobs, and Resilience. World Bank. https://doi.org/10.1596/34094

World Bank. (2021). Lao PDR Economic Monitor: Supporting Economic Recovery. The World Bank. http://pubdocs.worldbank.org/ en/306131610167443727/Lao-PDR-Economic-Monitor-January2021-Supporting-Economic-Recovery-Thematic-sectionLivelihoods-in-the-Time-of-COVID-19.pdf

Wright, J. H., Hill, N. A. O., Roe, D., Rowcliffe, J. M., Kümpel, N. F., Day, M., Booker, F., \& Milner-Gulland, E. J. (2016). Reframing the concept of alternative livelihoods. Conservation Biology, 30(1), 7-13. https://doi.org/10.1111/cobi.12607

Wunder, S., Angelsen, A., \& Belcher, B. (2014). Forests, Livelihoods, and Conservation: Broadening the Empirical Base. World Development, 64, S1-S11. https://doi.org/10.1016/j.worlddev.2014.03. 007

Publisher's Note Springer Nature remains neutral with regard to jurisdictional claims in published maps and institutional affiliations. 